Supporting Information

\title{
Unlocking the Allometric Growth and Dissolution of Zn Anodes at Initial Nucleation and Early Stage with Atomic Force Microscopy
}

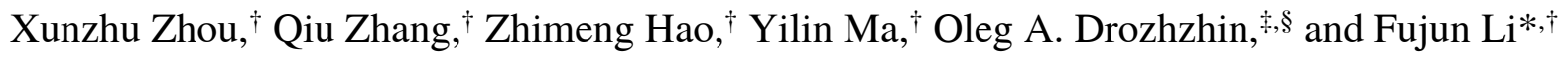

${ }^{\dagger}$ Key Laboratory of Advanced Energy Materials Chemistry (Ministry of Education), Renewable

Energy Conversion and Storage Centre (RECAST), College of Chemistry, Nankai University,

Tianjin 300071, P. R. China

Department of Chemistry, Lomonosov Moscow State University, Moscow 119991, Russia

§Skolkovo Institute of Science and Technology, Moscow 143026, Russia

E-mail: fujunli@nankai.edu.cn 

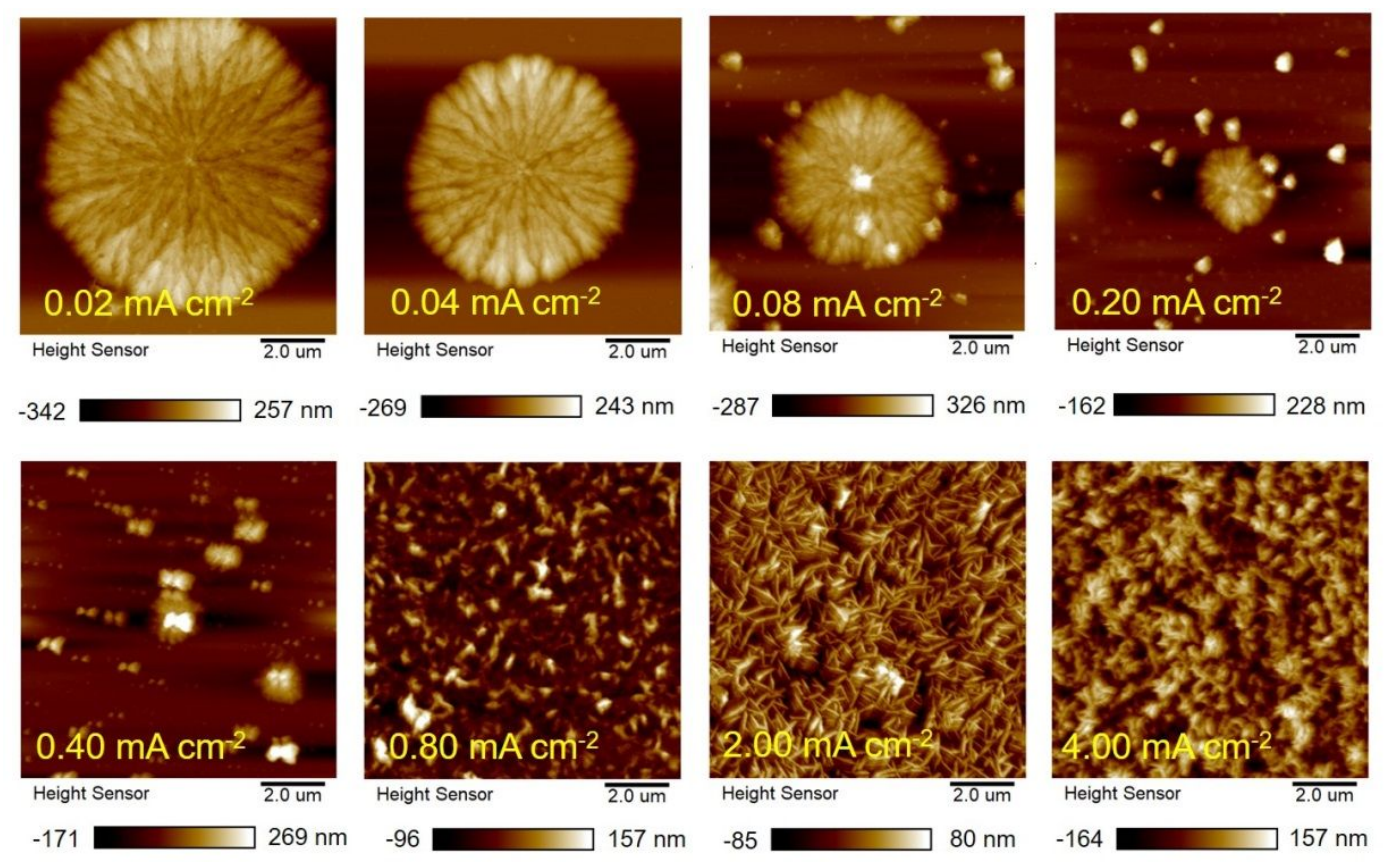

Figure S1. AFM images of $\mathrm{Zn}$ deposits after plating $0.028 \mathrm{mAh} \mathrm{cm}^{-2}$ on the home-made planar electrode with various current densities.

The initial nucleation radius and areal nuclei density are strikingly affected by the current density. Thus, an additional test was applied to screen out the optimal current density. As shown in Figure S1, different current densities from 0.02 to $4.00 \mathrm{~mA} \mathrm{~cm}^{-2}$ with a total charge of 0.028 $\mathrm{mAh} \mathrm{cm}^{-2}$ were applied on the working electrode in $1.0 \mathrm{~m} \mathrm{ZnCl}_{2}$ electrolyte. To unveil the morphology and distribution of initial $\mathrm{Zn}$ nuclei, $0.04 \mathrm{~mA} \mathrm{~cm}^{-2}$ was selected due to the moderate nuclei size and electrodepositing time.

At the very beginning of deposition, $\mathrm{Zn}^{2+}$ ions diffuse laterally along the surface and aggregate on the tiny protuberances due to the tip effect. $\mathrm{Zn}^{2+}$ ions deposit preferentially near the initial nuclei as a hemisphere to maintain the minimized surface energy. At the early growth stage, the fine nuclei grow along the plane to cover the electrode surface. Then, the threedimensional diffusion occurs after increasing the deposited capacity, leading to threedimensional stacked deposition and hence dendrite growth along vertical direction. The deposition with a large capacity contains the hemisphere nuclei and its later growth in 
lengthways. It will undergo the horizontal radial deposition until the electrode surface is covered and then grows along the vertical direction.

A large current density is beneficial to fine and dense initial nuclei according to the classical nucleation and growth theory shown in Note S1, but unfavorable for later uniform deposition due to the rapid reduction without sufficient $2 \mathrm{D}$ diffusion and formation of ion dissipation layer.

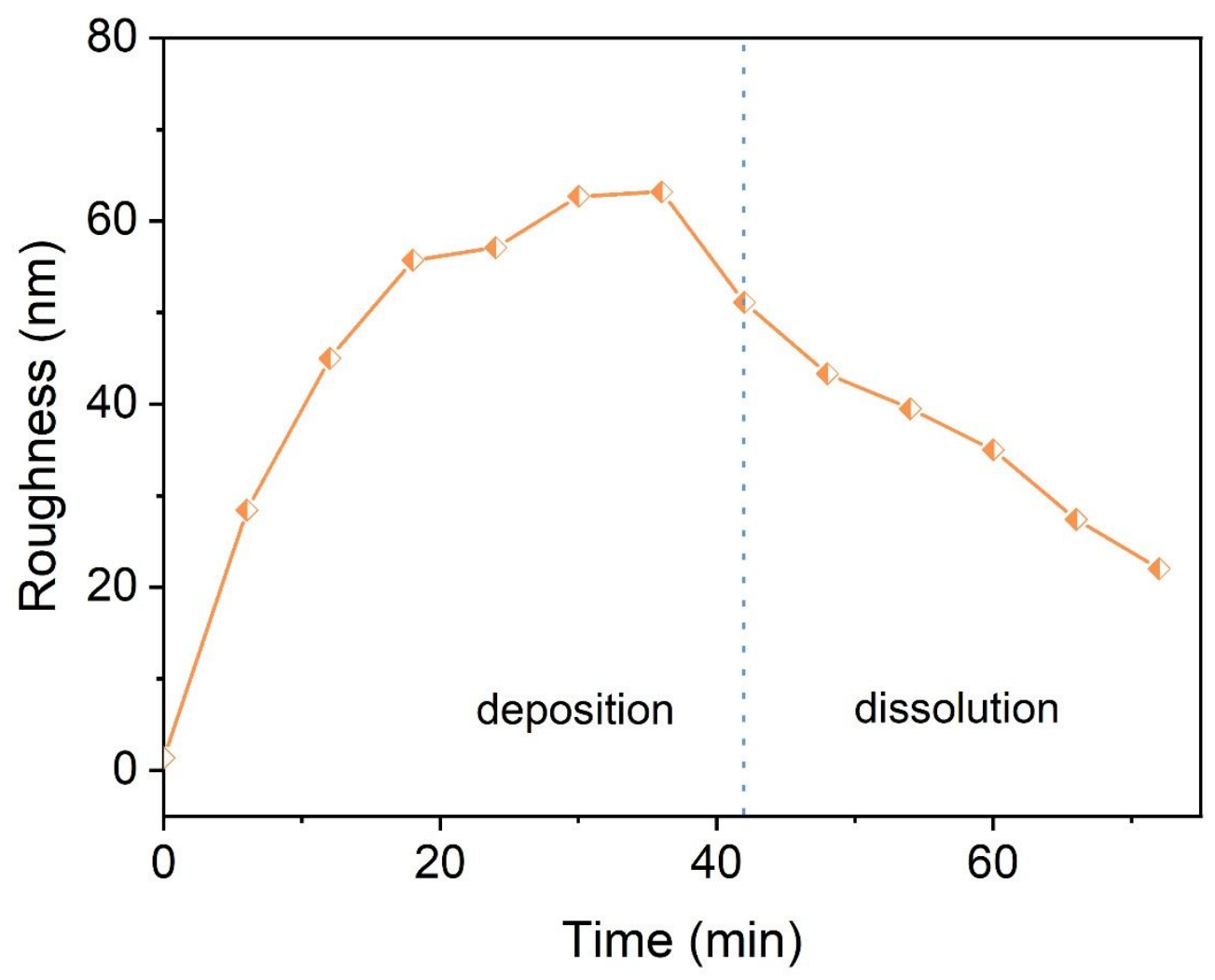

Figure S2. Roughness of in situ AFM images of $\mathrm{Zn}$ deposits during plating/stripping process in $5.0 \mathrm{~m} \mathrm{ZnCl}{ }_{2}$ electrolyte. 


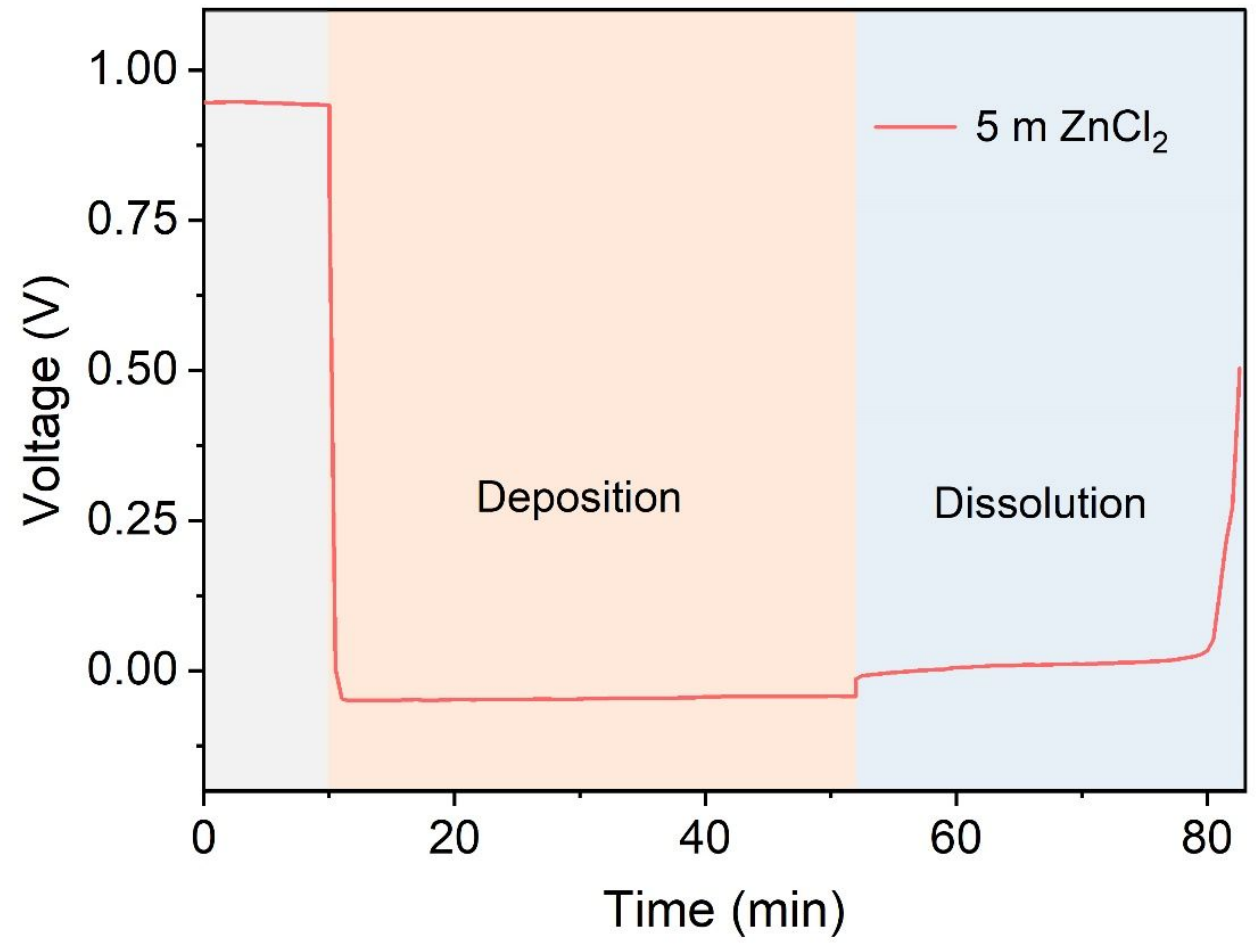

Figure S3. Galvanostatic curve of $\mathrm{Zn}$ deposition and dissolution in the in situ AFM tests. A current density of $0.04 \mathrm{~mA} \mathrm{~cm}{ }^{-2}$ with a total capacity of $0.028 \mathrm{mAh} \mathrm{cm}^{-2}$ was plated on the home-made planar electrode, and reversibly stripping until the voltage reached $0.5 \mathrm{~V}$ vs. $\mathrm{Zn}^{2+} / \mathrm{Zn}$. 

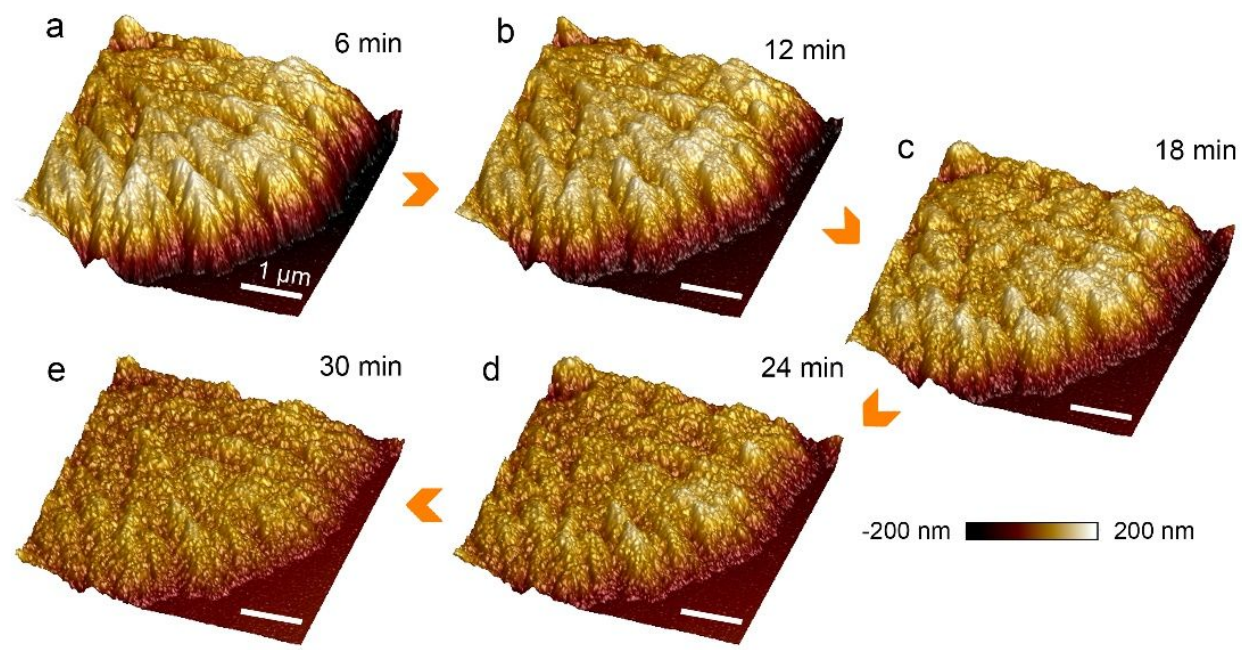

$-200 \mathrm{~nm}$

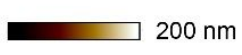

Figure S4. Enlarged three-dimensional AFM images during the dissolution of Zn deposits. 

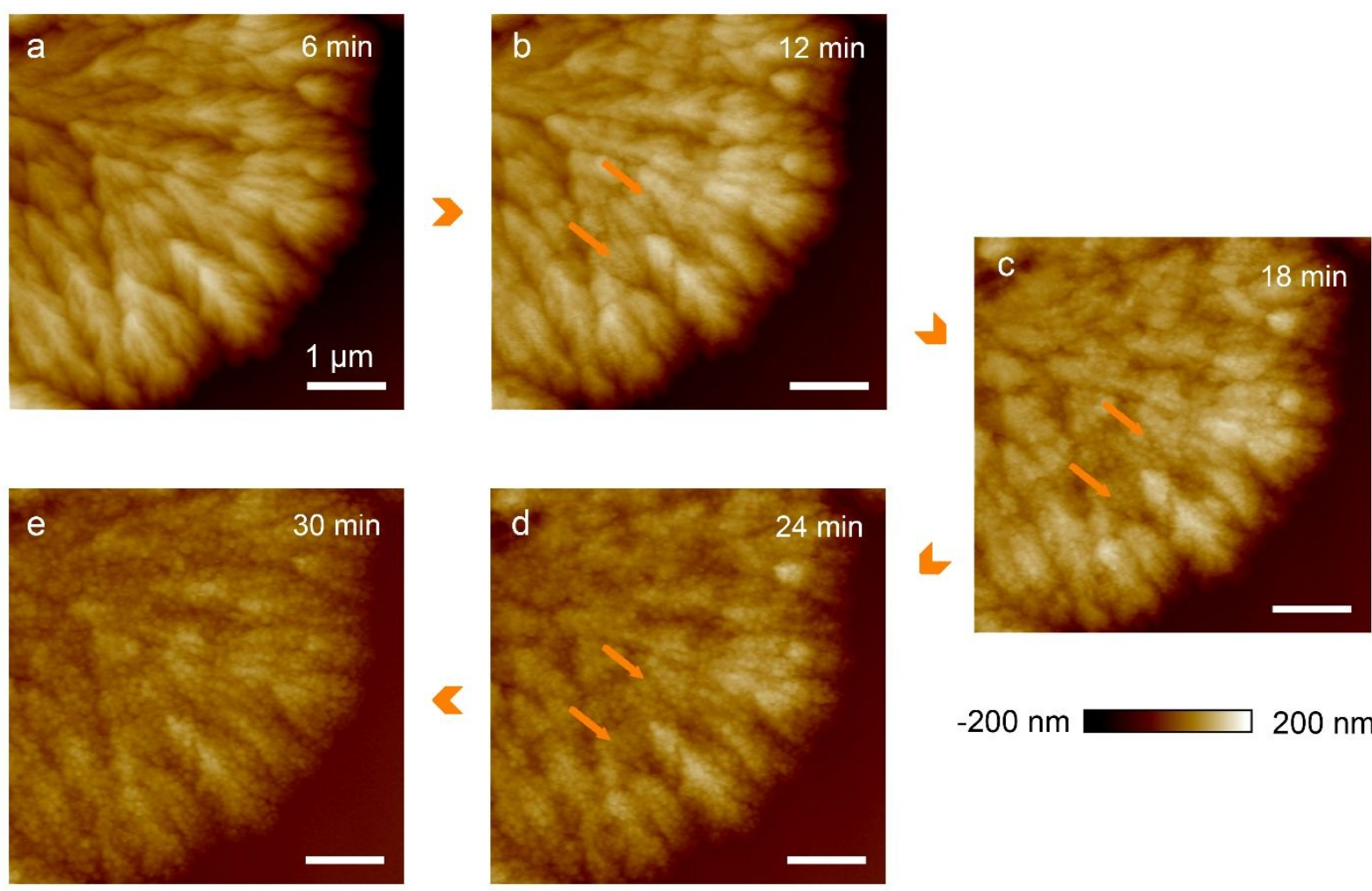

$-200 \mathrm{~nm}$

$200 \mathrm{~nm}$

Figure S5. Enlarged two-dimensional AFM images during the dissolution of Zn deposits. 


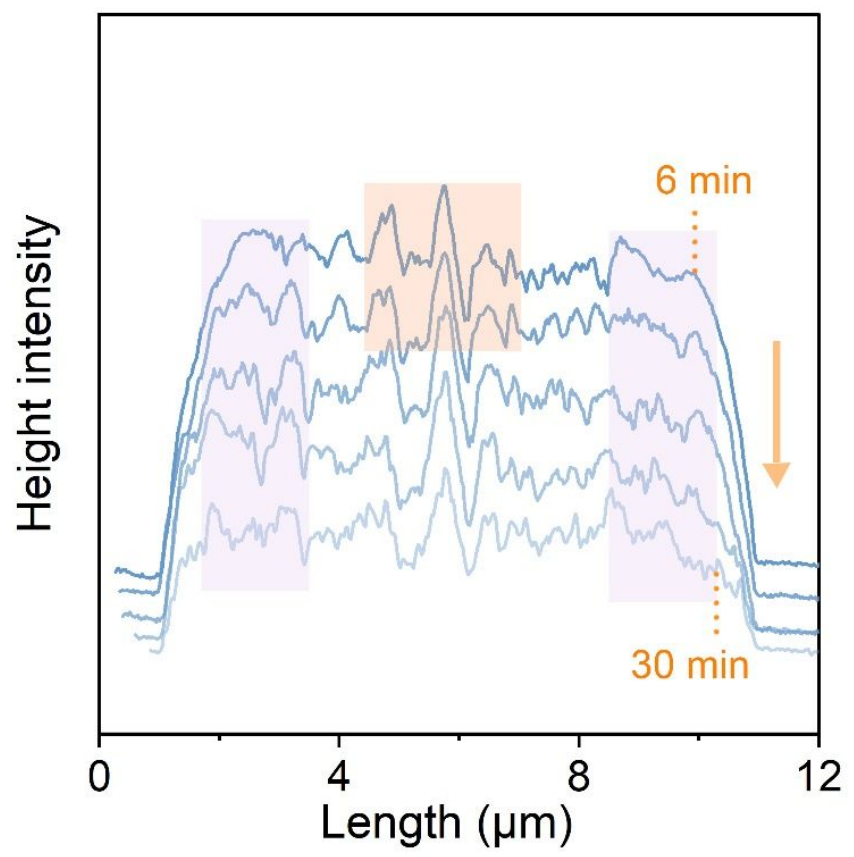

Figure S6. Cross-sectional height profiles of semi-spherical deposit during a dissolution process. Successive profiles have been progressively vertically displaced from each other for clearer visibility. 

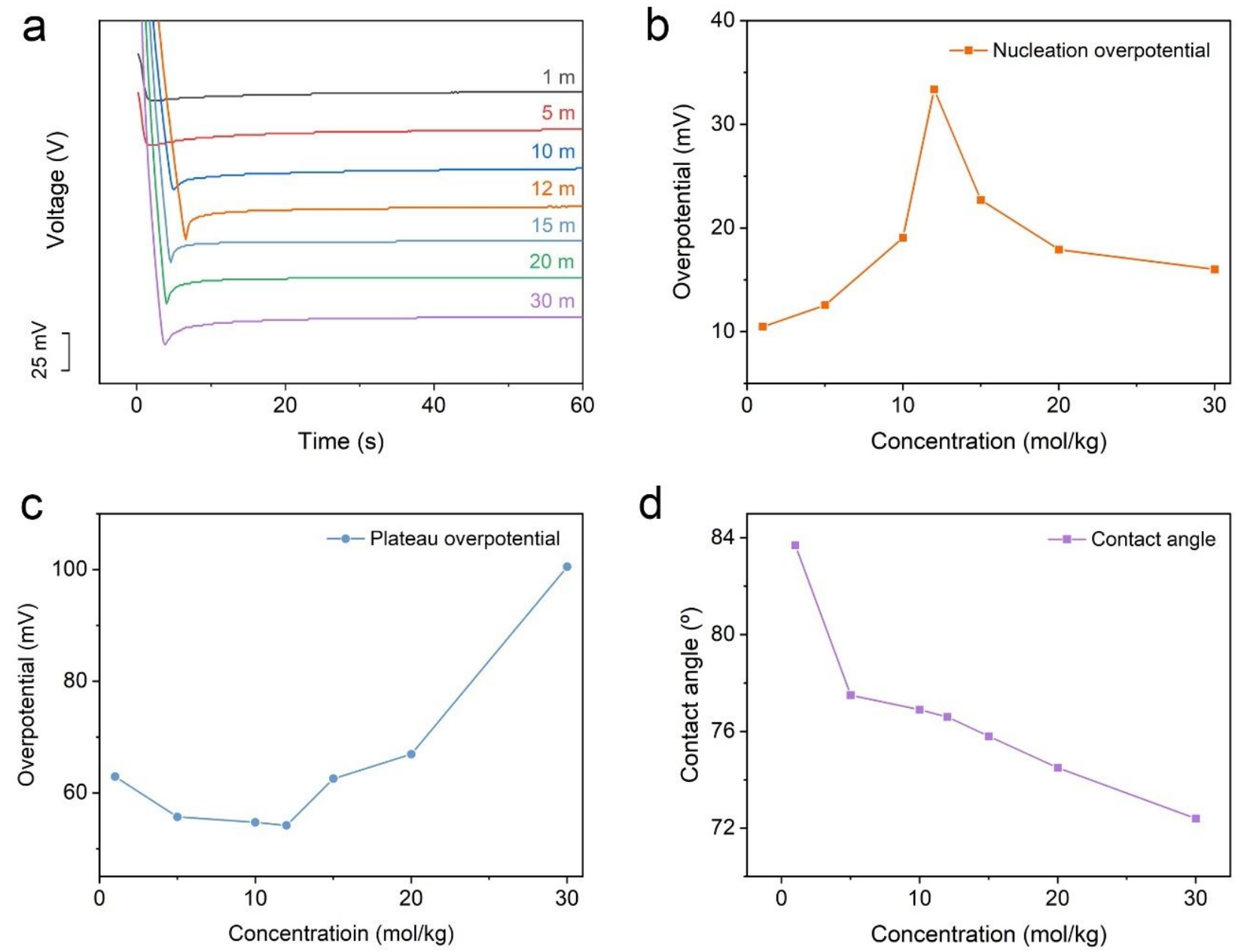

Figure S7. (a) Zn deposition curves in different electrolytes at $1.0 \mathrm{~mA} \mathrm{~cm}{ }^{-2}$. (b) Nucleation overpotential, (c) plateau overpotential, (d) contact angle verse electrolyte concentration. 

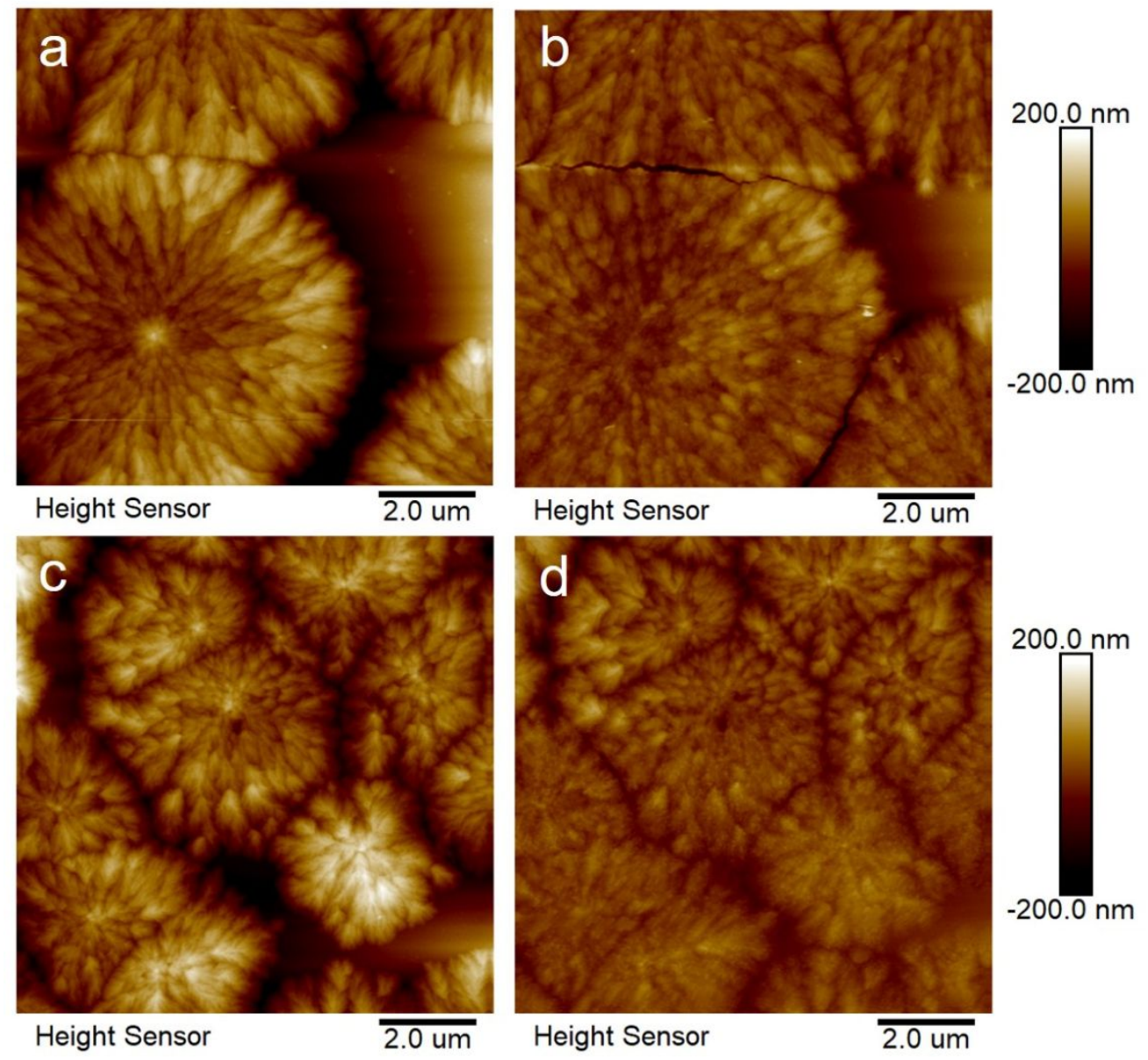

Figure S8. AFM images of $\mathrm{Zn}$ deposits in the $1.0 \mathrm{~m} \mathrm{ZnCl}_{2}$ electrolyte (a) before and (b) after dissolution. AFM images in $12.0 \mathrm{~m} \mathrm{ZnCl}$ electrolyte (c) before and (d) after dissolution. The top-down dissolution is consistent with the allometric model. 


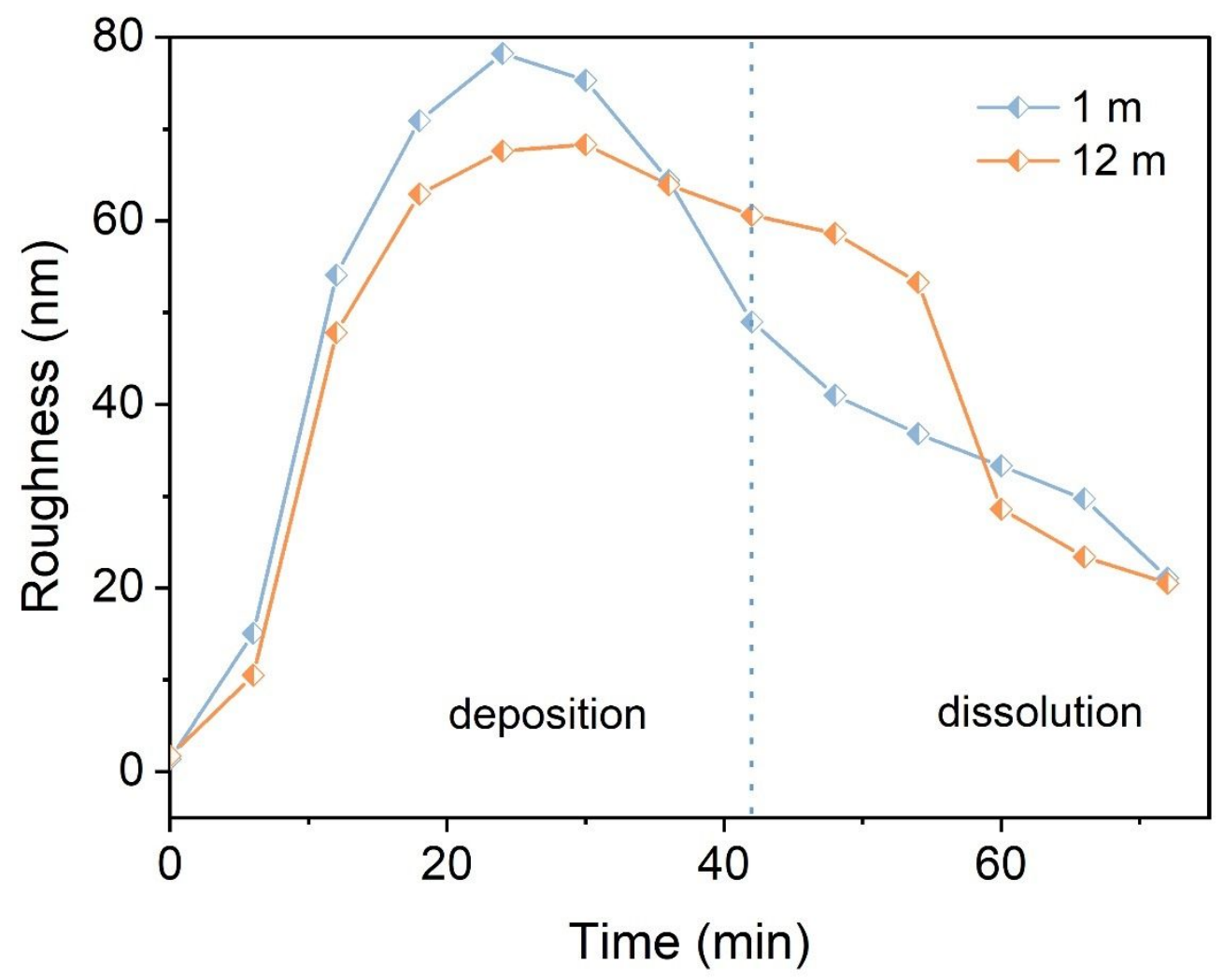

Figure S9. Roughness of in situ AFM images of Zn deposits during stripping/plating process in the $1.0 \mathrm{~m}$ and $12.0 \mathrm{~m} \mathrm{ZnCl}_{2}$ electrolytes. 

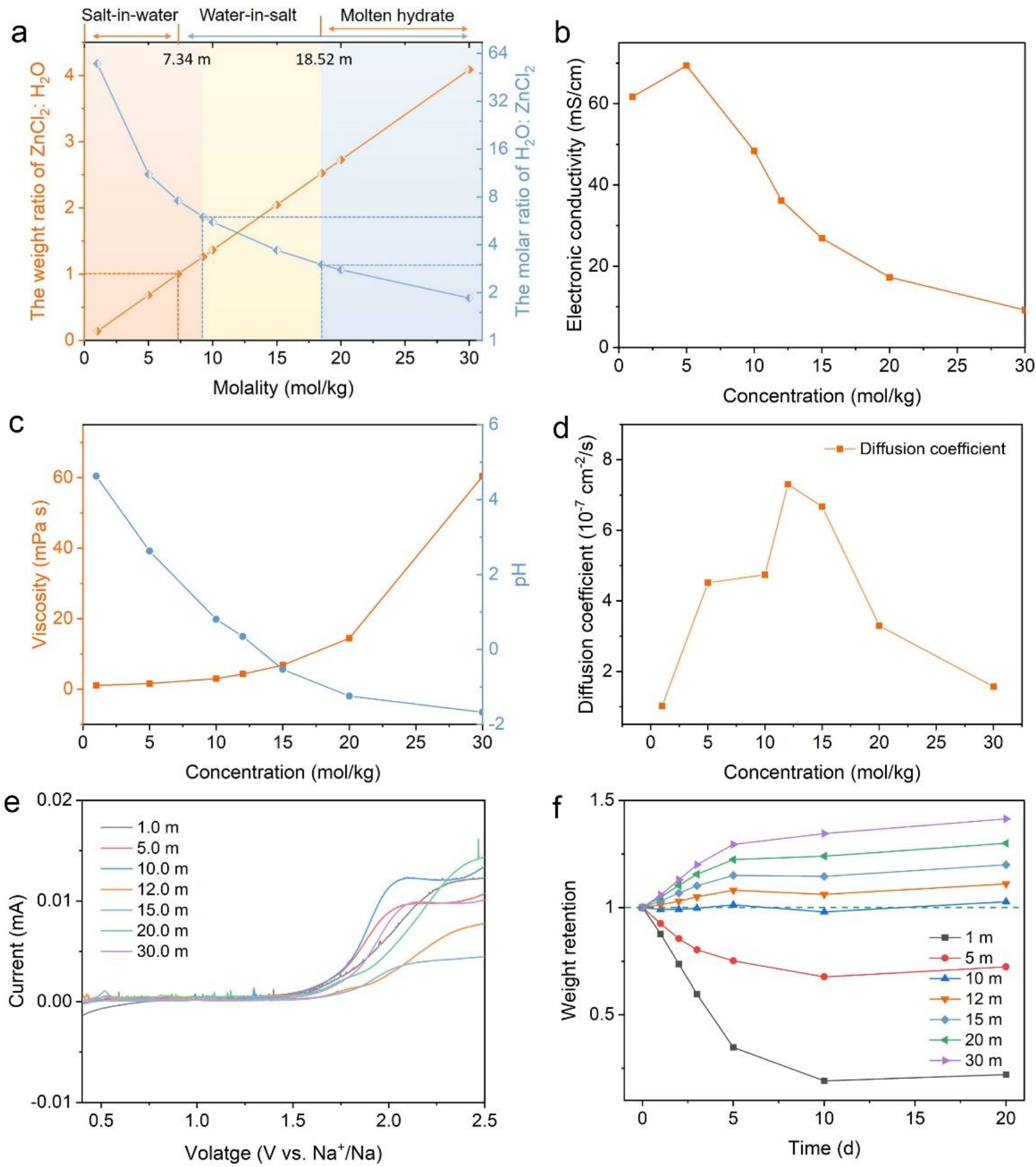

Figure S10. (a) Molarity of the $\mathrm{ZnCl}_{2}-\mathrm{H}_{2} \mathrm{O}$ binary system as the functions of the weight ratio of $\mathrm{ZnCl}_{2}$ to $\mathrm{H}_{2} \mathrm{O}$ and the molar ratio of $\mathrm{H}_{2} \mathrm{O}$ to $\mathrm{ZnCl}_{2}$. (b) Electronic conductivity, (c) viscosity and $\mathrm{pH}$ value, (d) diffusion coefficient and (e) cathodic stability versus electrolyte concentration. (f) Weight retention of various electrolytes at room temperature. 

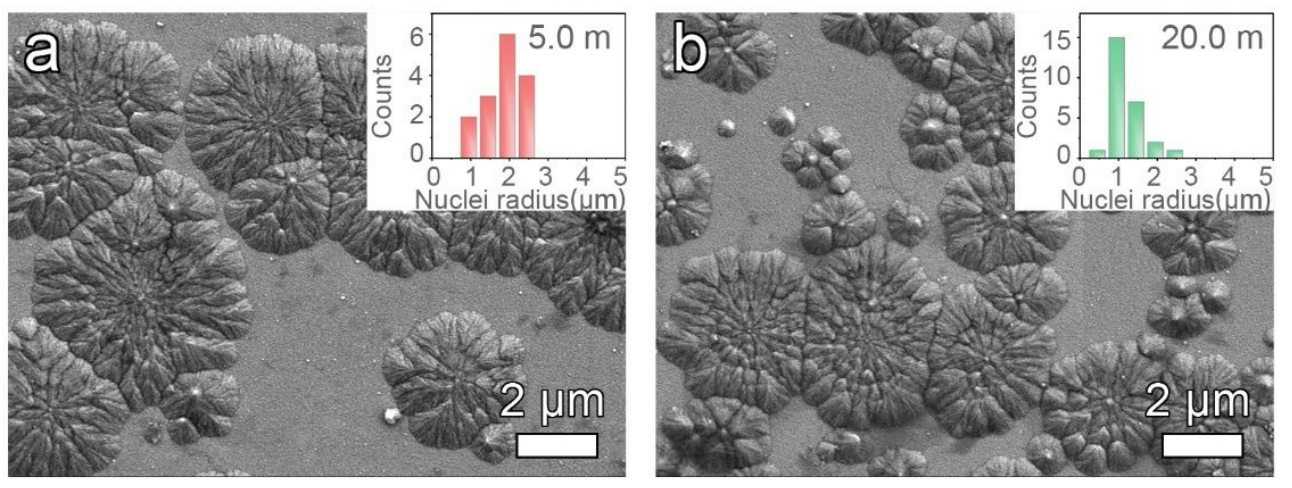

Figure S11. SEM images of $\mathrm{Zn}$ deposits in the (a) $5.0 \mathrm{~m}$ and (b) $20.0 \mathrm{~m} \mathrm{ZnCl}_{2}$ electrolyte on the home-made gold electrodes. Insets are their corresponding histograms of $\mathrm{Zn}$ particle sizes. 

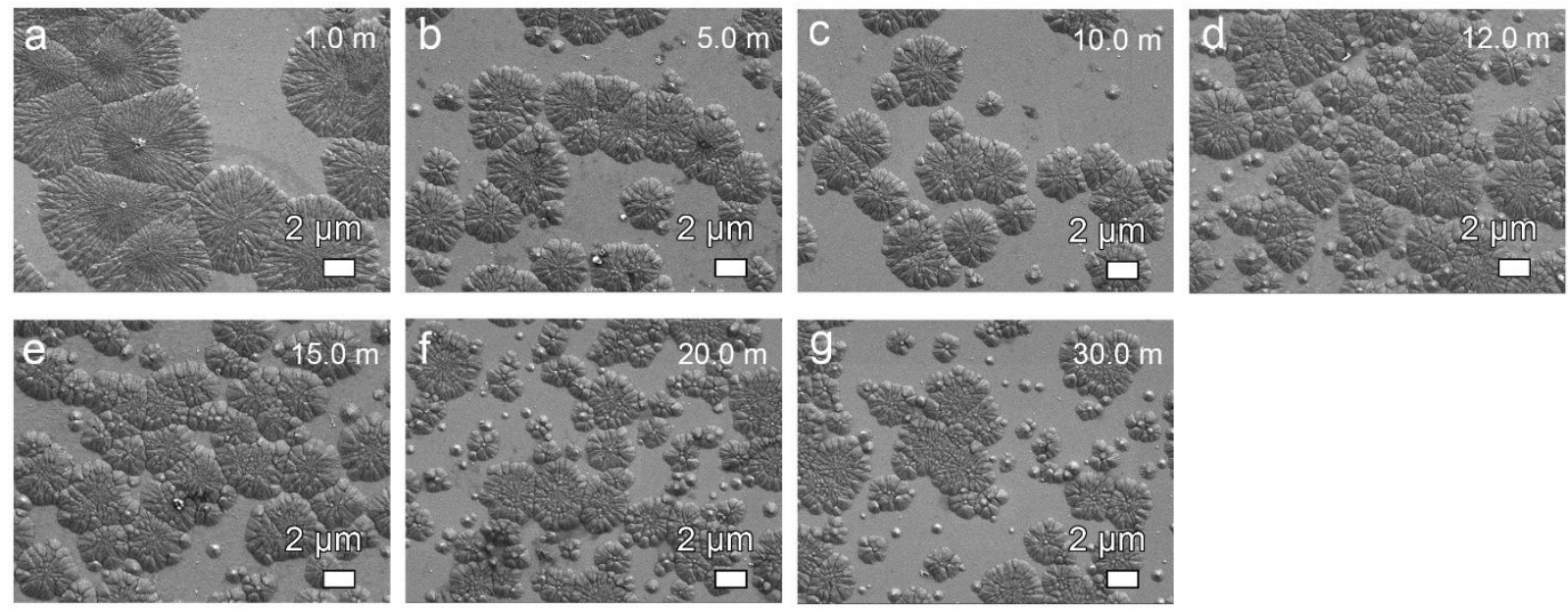

Figure S12. SEM images of the $\mathrm{Zn}$ deposits in various concentrations of $\mathrm{ZnCl}_{2}$ electrolyte with a smaller magnification than Figures 4a-e. 


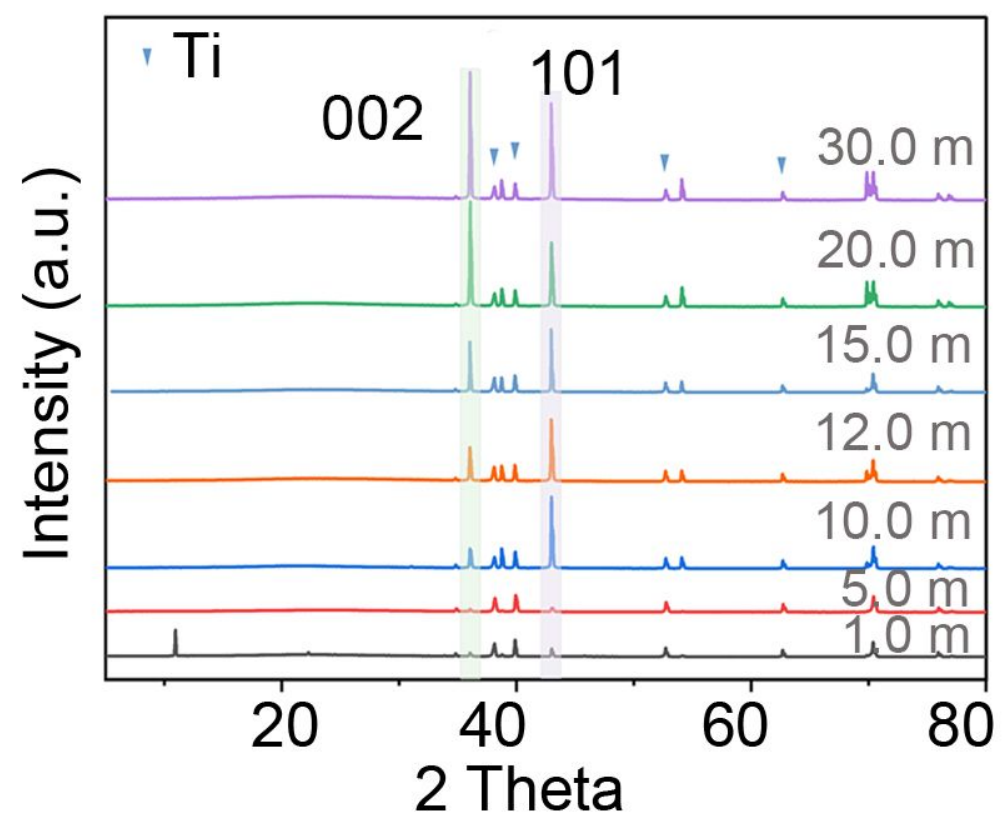

Figure S13. X-ray diffraction patterns of $\mathrm{Zn}$ deposits in various concentrations of $\mathrm{ZnCl}_{2}$ electrolyte.

Herein, we select two representative crystal orientations, (002) and (101), for further study. Deposited Zn on (101) has a higher current efficiency, but supports growth perpendicular to the electrode surface and accelerates dendrite growth and short circuiting. In contract, on the (002) surfaces, dendrite formation is less likely because (002) supports basal growth. ${ }^{1,2}$ The samples were prepared by plating $\mathrm{Zn}$ on titanium mesh with a current density of $1.0 \mathrm{~mA} \mathrm{~cm}-2$ for $1.0 \mathrm{mAh}$ $\mathrm{cm}^{-2}$. The peak intensities of all patterns are normalized by using the peak at $40.42^{\circ}$ of $\mathrm{Ti}$ as a reference. 

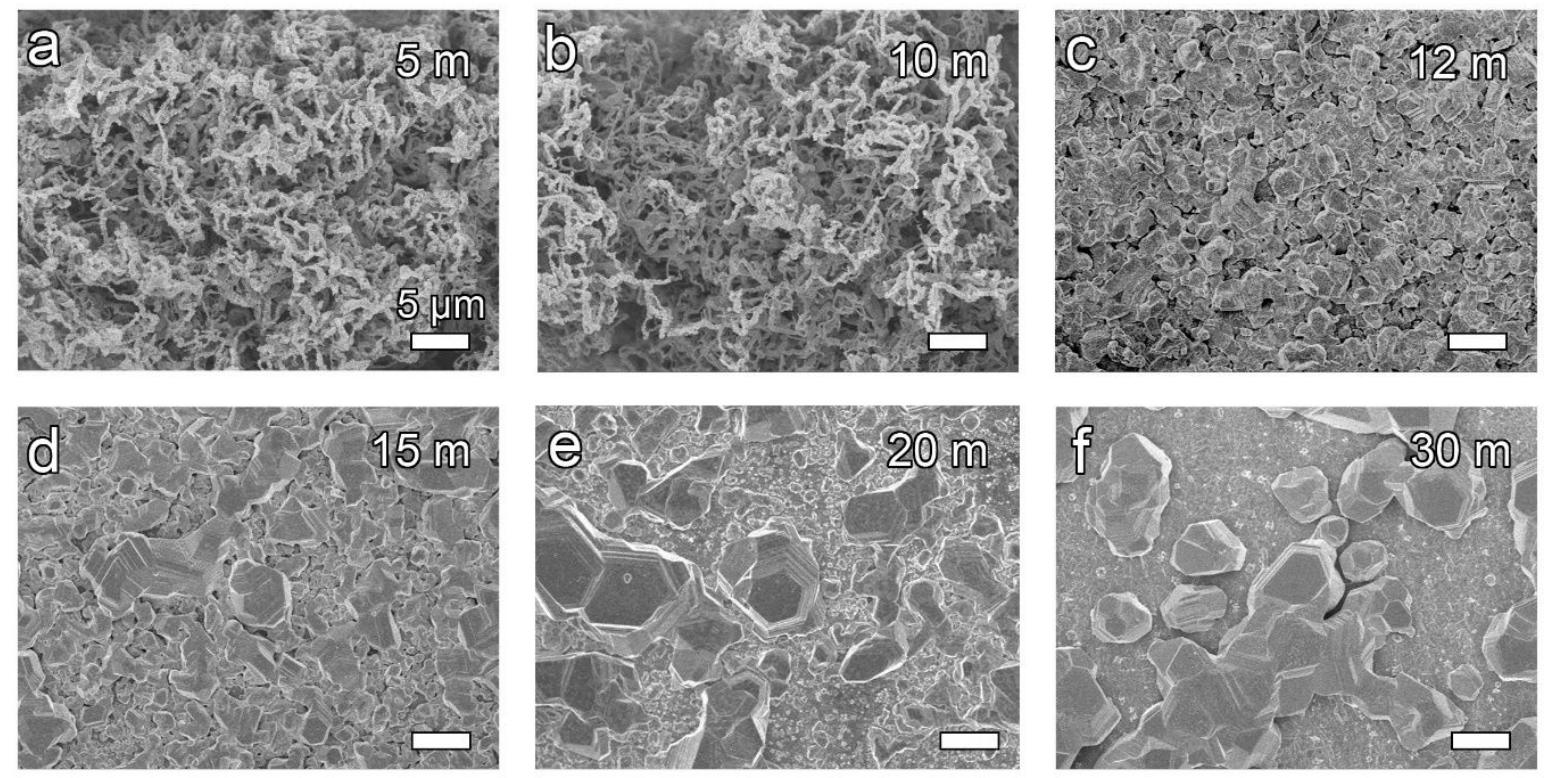

Figure S14. SEM images of deposited $\mathrm{Zn}$ at current density of $1.0 \mathrm{~mA} \mathrm{~cm}{ }^{-2}$ for $1 \mathrm{~h}$ on copper foils.

There are two different shapes of deposited Zn: fine-size filamentous dendrites and well-defined hexagonal crystals. In dilute electrolytes, deposited $\mathrm{Zn}$ is amorphous and presents as porous needle-like crystals with uniform sizes. This structure provides huge contact area between porous $\mathrm{Zn}$ and electrolyte, which accelerates side reactions and leads to low utilization of $\mathrm{Zn}$. In the intermediate and high concentrated electrolytes, sediments are the hexagonal Zn plates, which are parallel to the substrate and less likely to form the dendrites. In the wide concentration range from the $12.0 \mathrm{~m}$ to $30.0 \mathrm{~m} \mathrm{ZnCl}_{2}$ electrolyte, the density of crystals decreases and their size increases from $\sim 2.5 \mu \mathrm{m}$ to $\sim 7.0 \mu \mathrm{m}$, which is fully consistent with the trends from the classical nucleation and growth theory in Figure $2 \mathrm{f}$. 

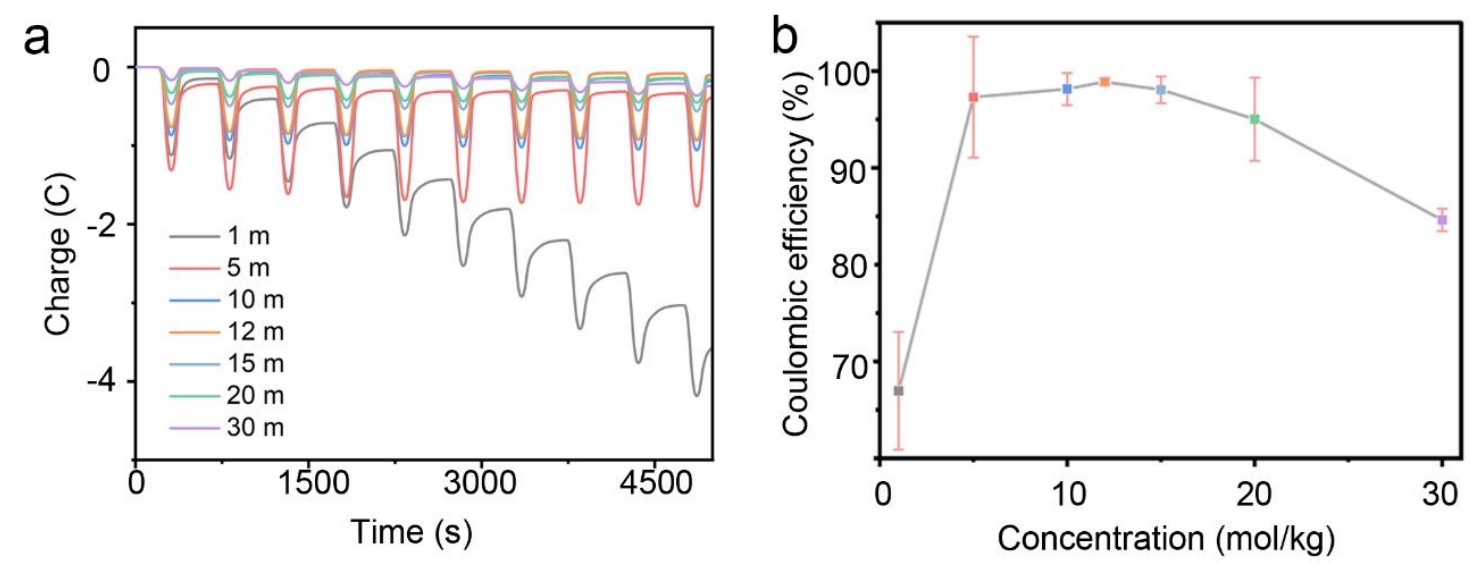

Figure S15. (a) Chronocoulometry curves of Zn stripping/plating in a three-electrode cell in various electrolytes. (b) Average Coulombic efficiency of first 10 stripping/plating cycles with error bars.

The reversibility of $\mathrm{Zn}$ plating/stripping was further investigated by cyclic voltammetry, in which a titanium mesh $(1 \times 1 \mathrm{~cm})$ is used as the working electrode and $\mathrm{Zn}$ foil $(1 \times 1 \mathrm{~cm})$ is used as the reference and counter electrodes. Coulombic efficiency (CE) was calculated by the chronocoulometry curves shown in Figure S14a. The average CE with its error bar is displayed in Figure S14b, meanwhile, the specific value of every cycle in different electrolyte is also available in Table S4. 

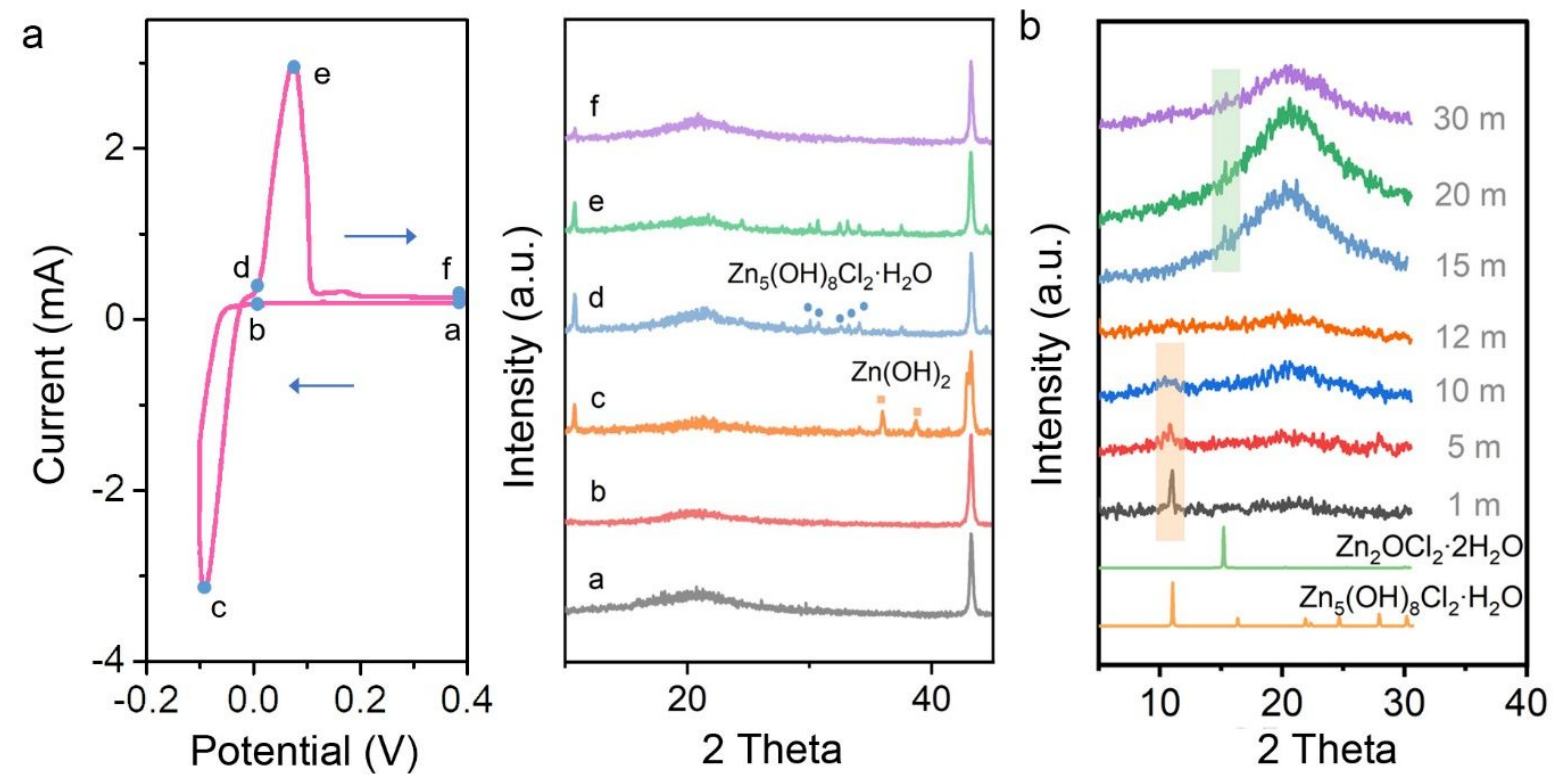

Figure S16. (a) CV curve at $1.0 \mathrm{mV} \mathrm{s}^{-1}$ and corresponding ex situ XRD patterns at the stages of a-f as marked on CV curve. (b) XRD pattern of passivated products in various concentrated $\mathrm{ZnCl}_{2}$ electrolytes. The samples were prepared from $\mathrm{Zn}|| \mathrm{Ti}$ asymmetric cells after 10 cycles.

To illustrate the chemical components of passivated products, ex situ XRD in the $5.0 \mathrm{~m} \mathrm{ZnCl} 2$ electrolyte is conducted at the stages of a-f as marked on the CV curve. When swept to $-0.2 \mathrm{~V}$, the new diffraction peaks at $31.83^{\circ}$ and $34.47^{\circ}$ are attributed to zinc hydroxide $\mathrm{Zn}(\mathrm{OH})_{2}$. As the potential is scanned anodically from -0.2 to $0 \mathrm{~V}, \mathrm{Zn}(\mathrm{OH})_{2}$ disappears and transforms into $\mathrm{Zn}_{5}(\mathrm{OH}$ )$_{8} \mathrm{Cl}_{2} \cdot \mathrm{H}_{2} \mathrm{O}$, which dissolves incompletely during the anodic scan. The accumulated passivated products in $\mathrm{Zn} \| \mathrm{Ti}$ cells after 10 cycle are observed in Figure S16b, which assumed large amounts of active $\mathrm{Zn}$, demonstrate the decreased $\mathrm{Zn}^{2+}$ ions concentration during the operation of ZIBs. With the increase of $\mathrm{ZnCl}_{2}$ salt, the passivated product changes with the content of free water molecules: $\mathrm{Zn}_{5}(\mathrm{OH})_{8} \mathrm{Cl}_{2} \cdot \mathrm{H}_{2} \mathrm{O}$ in dilute electrolytes and $\mathrm{Zn}_{2} \mathrm{OCl}_{2} \cdot 2 \mathrm{H}_{2} \mathrm{O}$ in moderate or high concentrated electrolytes as the Equations 1-2 show. The by-product is different to be observed in the $12.0 \mathrm{~m} \mathrm{ZnCl}_{2}$ electrolyte because of its high $\mathrm{Zn}$ plating/stripping. However, limited by the detection limit of XRD instrument and the acidic solution, the signals of alkaline passivated products is weak.

$$
\begin{aligned}
& 4 \mathrm{Zn}+\mathrm{ZnCl}_{2}+9 \mathrm{H}_{2} \mathrm{O} \rightarrow \mathrm{Zn}_{5}(\mathrm{OH})_{8} \mathrm{Cl}_{2} \cdot \mathrm{H}_{2} \mathrm{O} \downarrow+4 \mathrm{H}_{2} \uparrow \\
& \mathrm{Zn}+\mathrm{ZnCl}_{2}+3 \mathrm{H}_{2} \mathrm{O} \rightarrow \mathrm{Zn}_{2} \mathrm{OCl}_{2} \cdot 2 \mathrm{H}_{2} \mathrm{O} \downarrow+\mathrm{H}_{2} \uparrow
\end{aligned}
$$




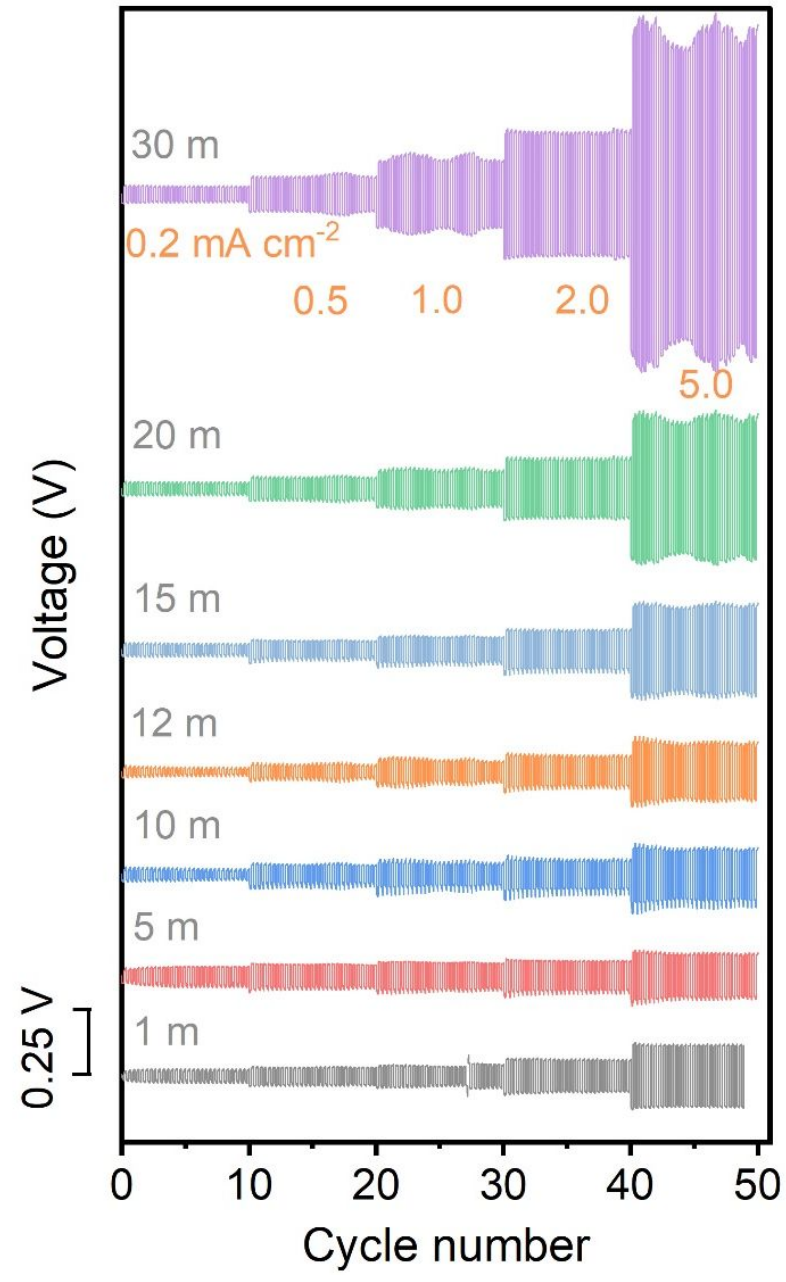

Figure S17. $\mathrm{Zn}|| \mathrm{Zn}$ symmetric cell at different scan rates for calculating the exchange current density. 

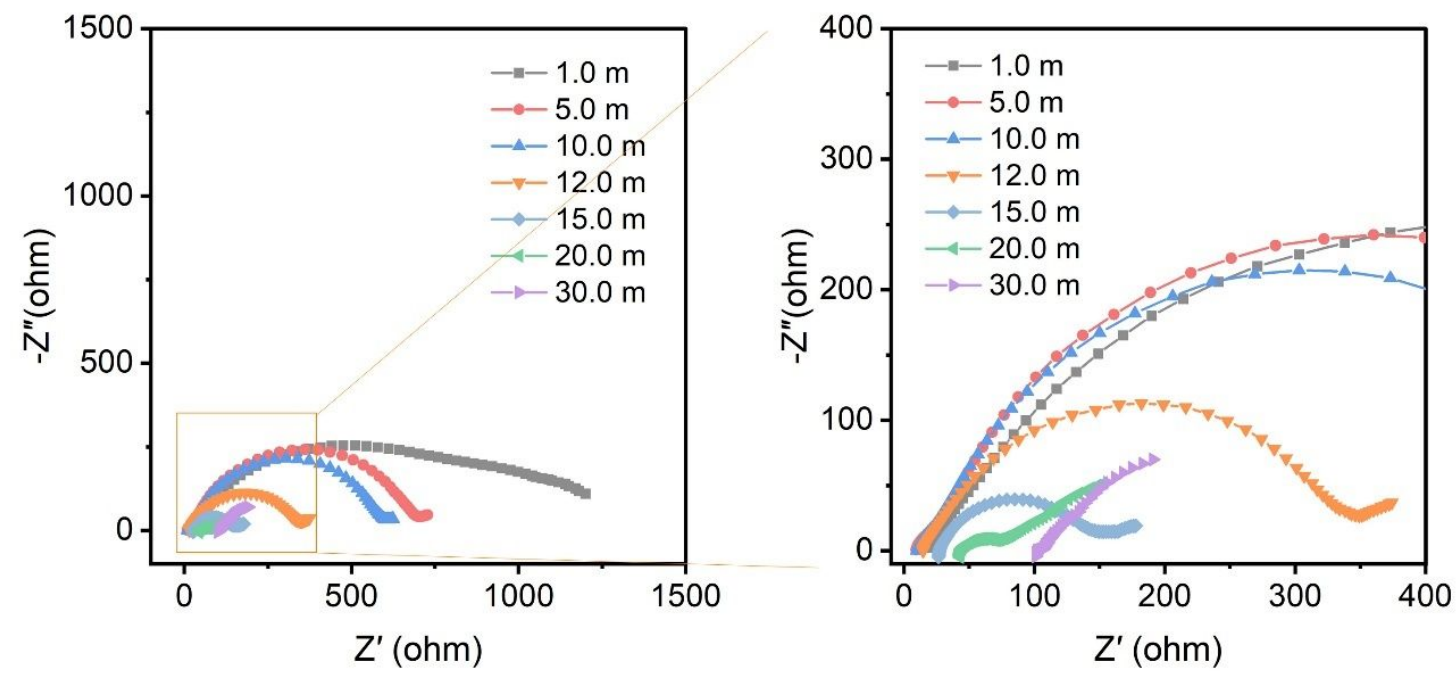

Figure S18. Electrochemical impedance spectroscopy (EIS) of the $\mathrm{Zn} \| \mathrm{Zn}$ symmetric cells in various concentrated electrolytes over a frequency range from $100 \mathrm{kHz}$ to $0.1 \mathrm{~Hz}$. 

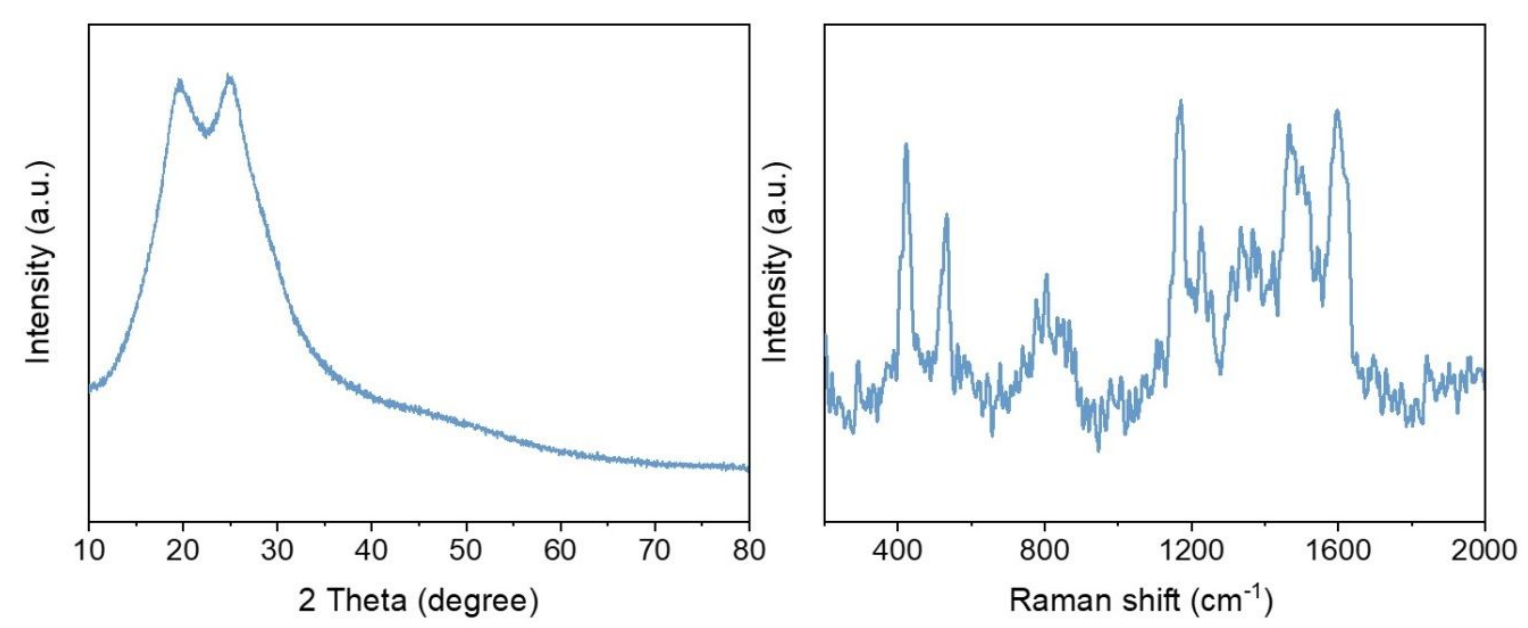

Figure S19. (a) XRD and (b) Raman of synthetic PANI nanorods.

The diffraction peaks at $19.7^{\circ}$ and $25.7^{\circ}$ correspond to (020) and (200) crystal plane of PANI. In Raman spectra, some characteristic stretching vibrations of PANI were observed, such as the CC out-of-plane deformation at 420/518 $\mathrm{cm}^{-1}$, the out of-plane $\mathrm{C}-\mathrm{H}$ motion at $806 \mathrm{~cm}^{-1}$, the C-H bending at $1168 \mathrm{~cm}^{-1}$, the $v \mathrm{C}-\mathrm{N}$ benzene diamine units at $1232 \mathrm{~cm}^{-1}$, the $v \mathrm{C}-\mathrm{N}^{+}$at $1334 \mathrm{~cm}^{-1}$, the $\nu \mathrm{C}=\mathrm{N}$ at $1498 \mathrm{~cm}^{-1}$ and the $\mathrm{C}=\mathrm{N}$ stretching vibrations of benzenoid rings at $1591 \mathrm{~cm}^{-1}$, indicating the high purity of the synthetic PANI. ${ }^{3}$ 

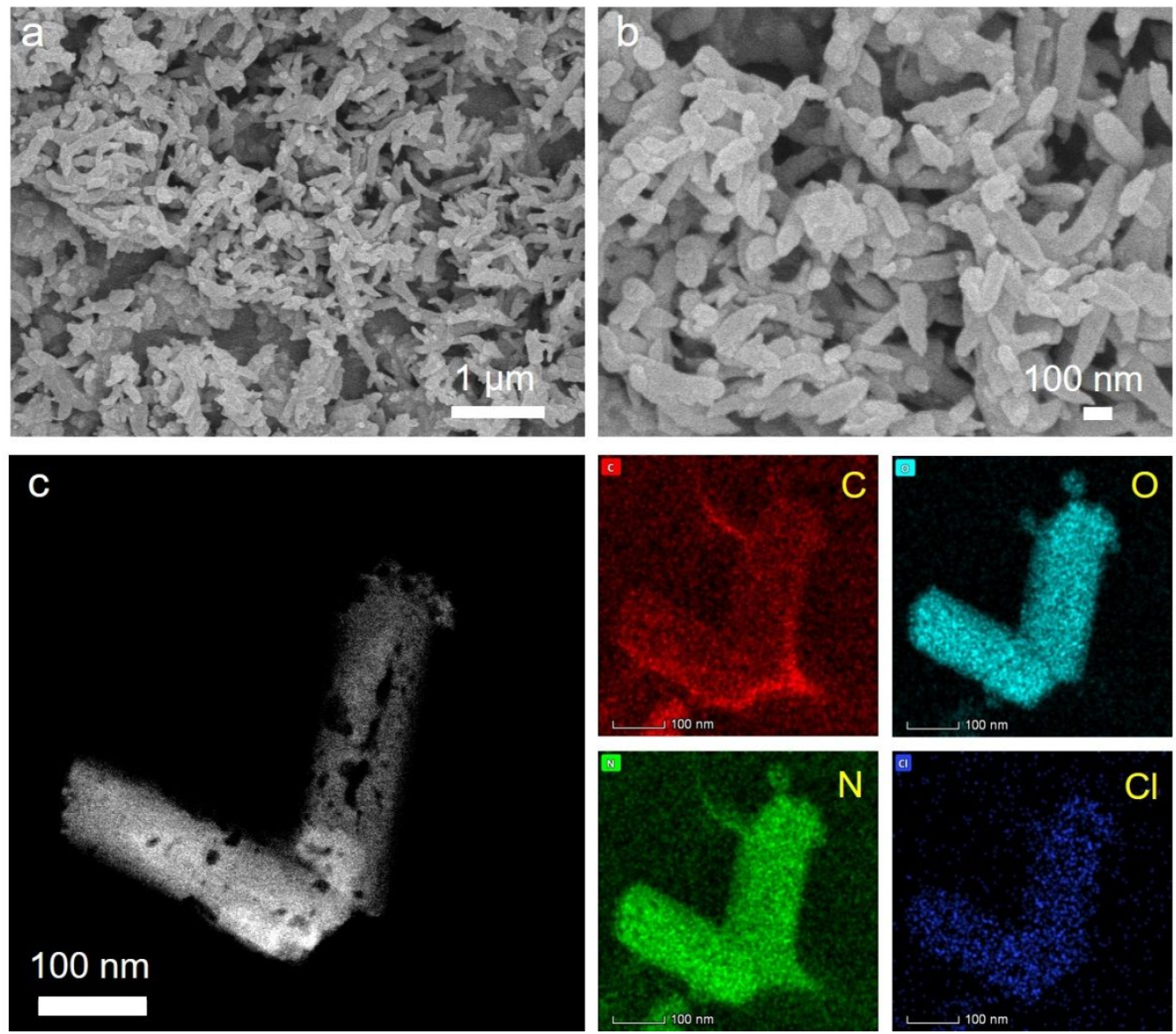

Figure S20. (a-b) SEM and (c) TEM elemental mapping images of synthetic PANI nanorods. 


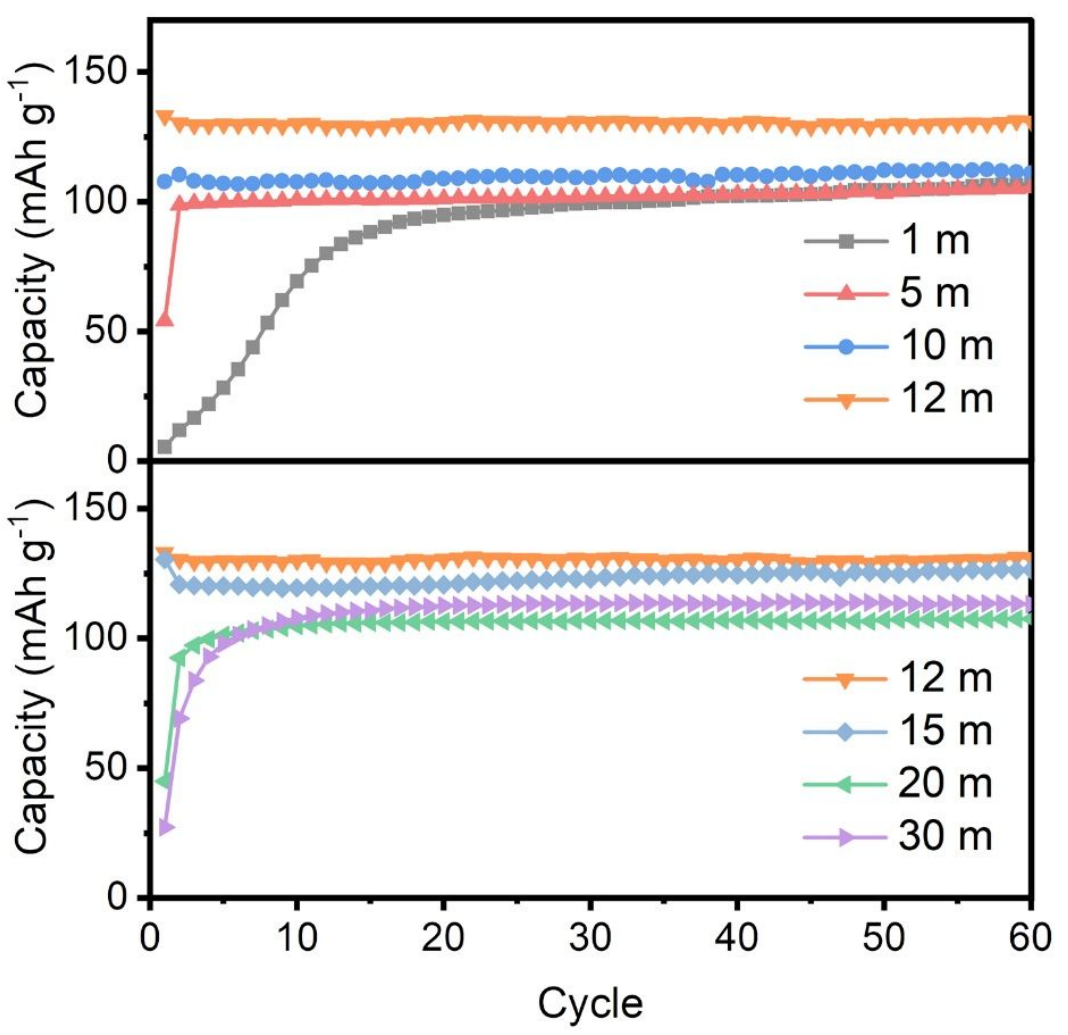

Figure S21. Electrochemical performance of Zn\|PANI full cells in various electrolytes at $50 \mathrm{~mA}$ $\mathrm{g}^{-1}$. 

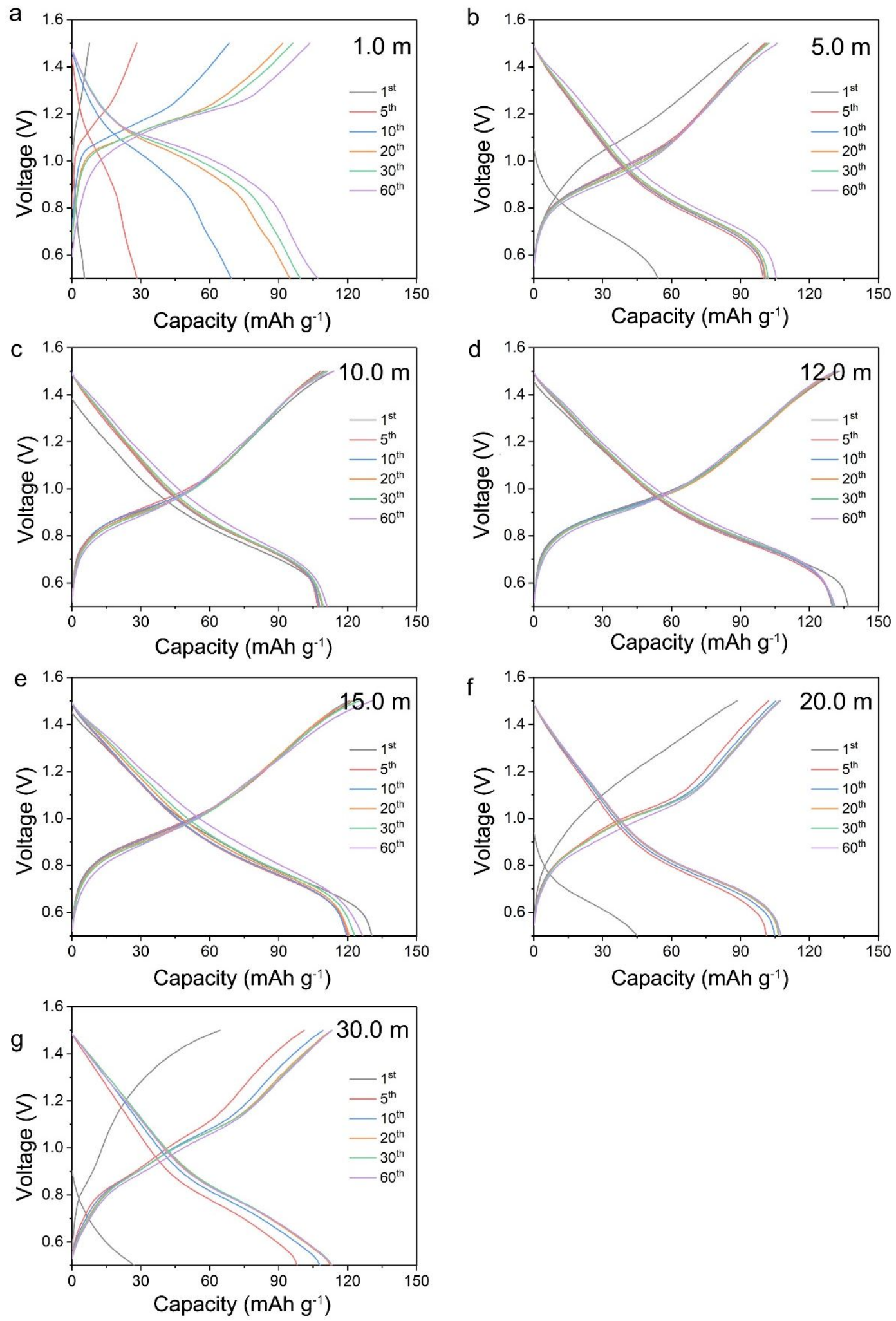

Figure S22. Charge-discharge curve of Zn||PANI full cells in various concentrated electrolytes between 0.5 and $1.5 \mathrm{~V}$ vs. $\mathrm{Zn}^{2+} / \mathrm{Zn}$ in the $1^{\text {st }}, 5^{\text {th }}, 10^{\text {th }}, 20^{\text {th }}, 30^{\text {th }}$ and $60^{\text {th }}$ cycle. 


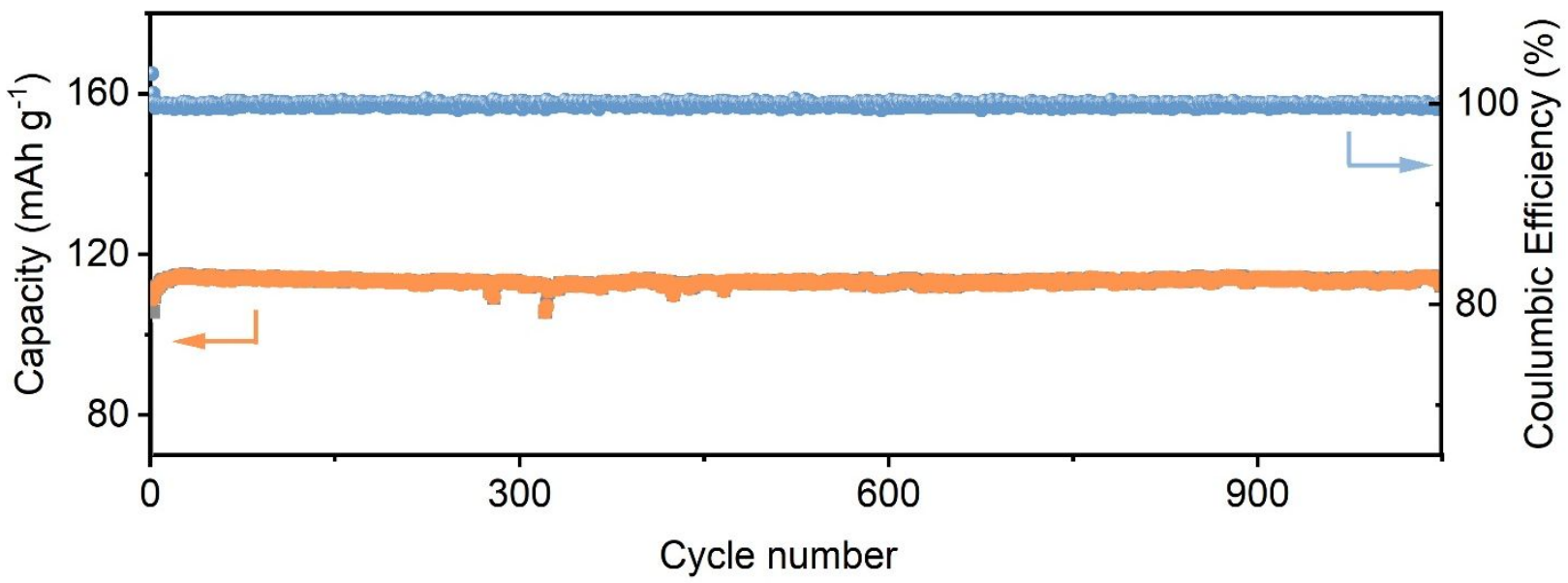

Figure S23. Long-term cycling performance in the $12.0 \mathrm{~m} \mathrm{ZnCl}_{2}$ electrolyte at $500 \mathrm{~mA} \mathrm{~g}^{-1}$ in $\mathrm{Zn} \|$ PANI cell. 

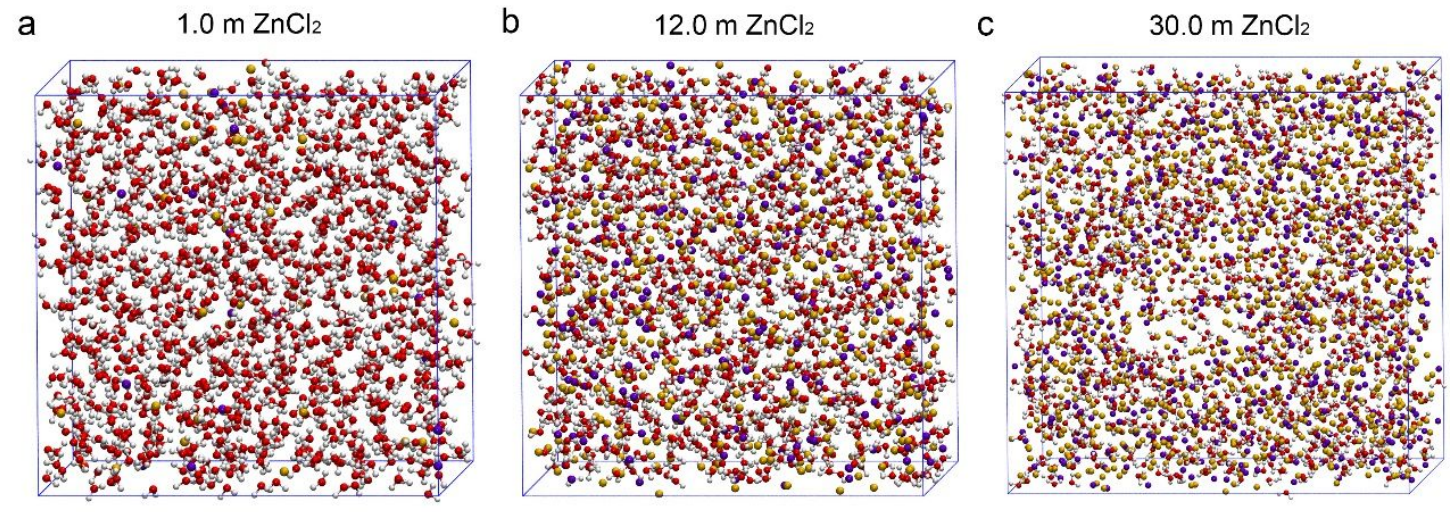

Figure S24. MD simulation snapshots of the (a) $1.0 \mathrm{~m} \mathrm{ZnCl}_{2}$, (b) $12.0 \mathrm{~m} \mathrm{ZnCl}_{2}$, and (c) $30.0 \mathrm{~m}$ $\mathrm{ZnCl}_{2}$ electrolyte at $303 \mathrm{~K}$ 

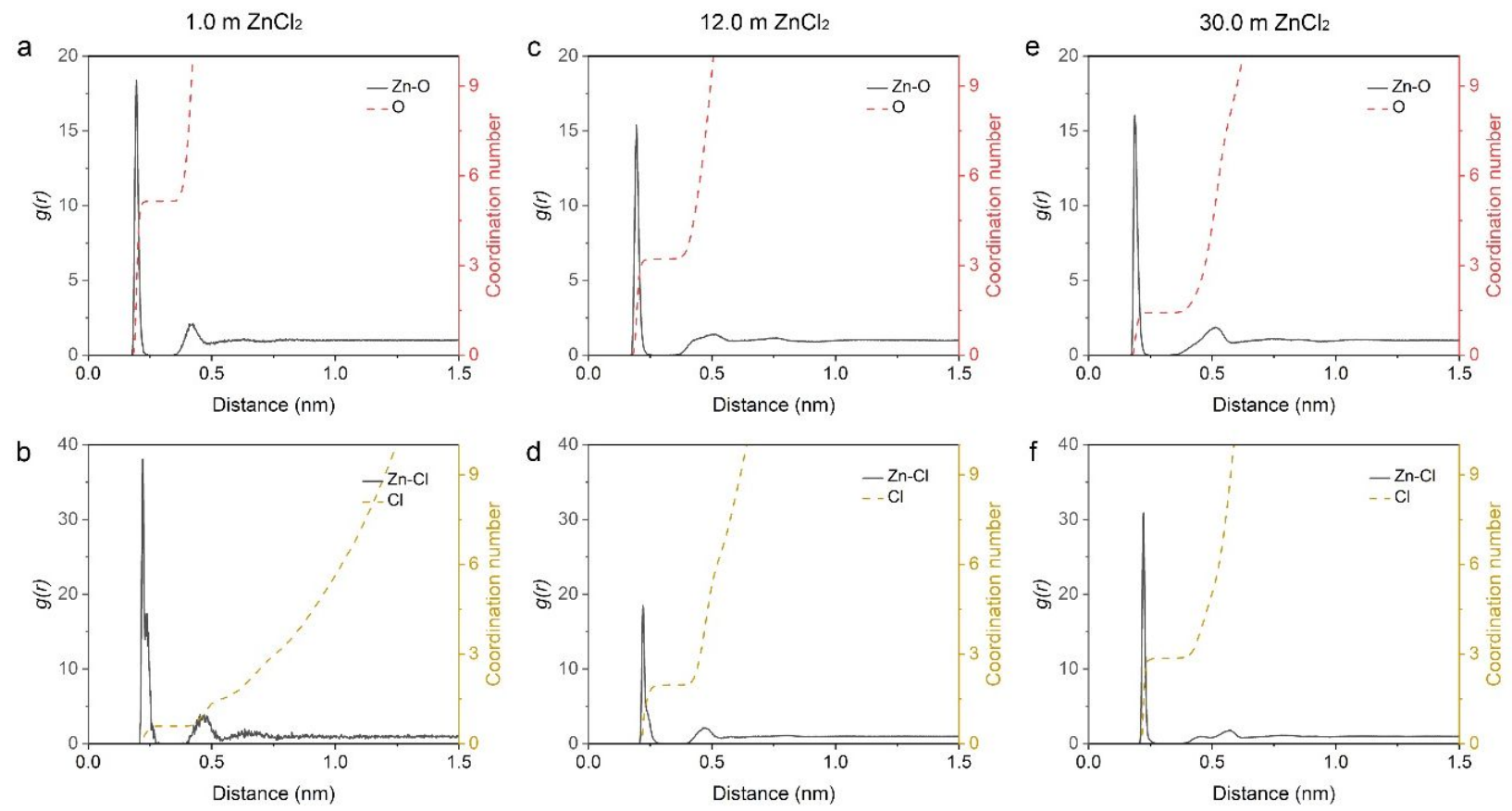

Figure S25. Radial distribution functions $g(r)$ and corresponding coordination number calculated from MD simulation of $\mathrm{Zn}-\mathrm{O}$ and $\mathrm{Zn}-\mathrm{Cl}$ pairs in the (a-b) $1.0 \mathrm{~m} \mathrm{ZnCl}_{2}$, (c-d) $12.0 \mathrm{~m} \mathrm{ZnCl}_{2}$, and (e-f) $30.0 \mathrm{~m} \mathrm{ZnCl} 2$ electrolyte at $303 \mathrm{~K}$. 


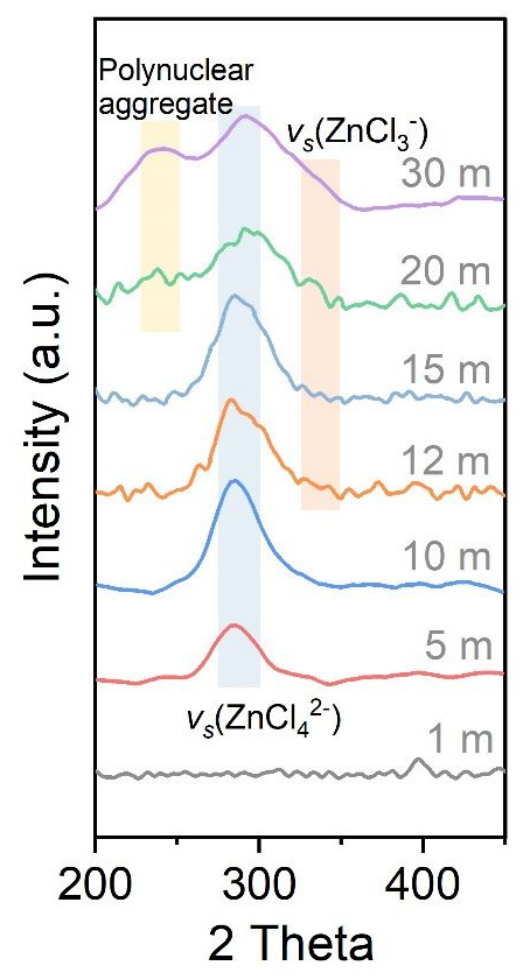

Figure S26. Raman spectra of various concentrated electrolytes.

The band at $285 \mathrm{~cm}^{-1}$ is assigned to the symmetric stretching mode of $\left[\mathrm{ZnCl}_{4}\right]^{2-}$. The band at 330 $\mathrm{cm}^{-1}$ is assigned to the stretching mode of $\left[\mathrm{ZnCl}_{3}\right]^{-}$or $\mathrm{ZnCl}_{2}$. With the increase of $\mathrm{ZnCl}_{2}$ content, the main peak at around $285 \mathrm{~cm}^{-1}$ becomes broader and gradually shifts to $291 \mathrm{~cm}^{-1}$. The band at $237 \mathrm{~cm}^{-1}$ is assigned to the polynuclear aggregation of $\left[\mathrm{ZnCl}_{4}\right]^{2-}$. It means formation of incomplete hydration shells. 

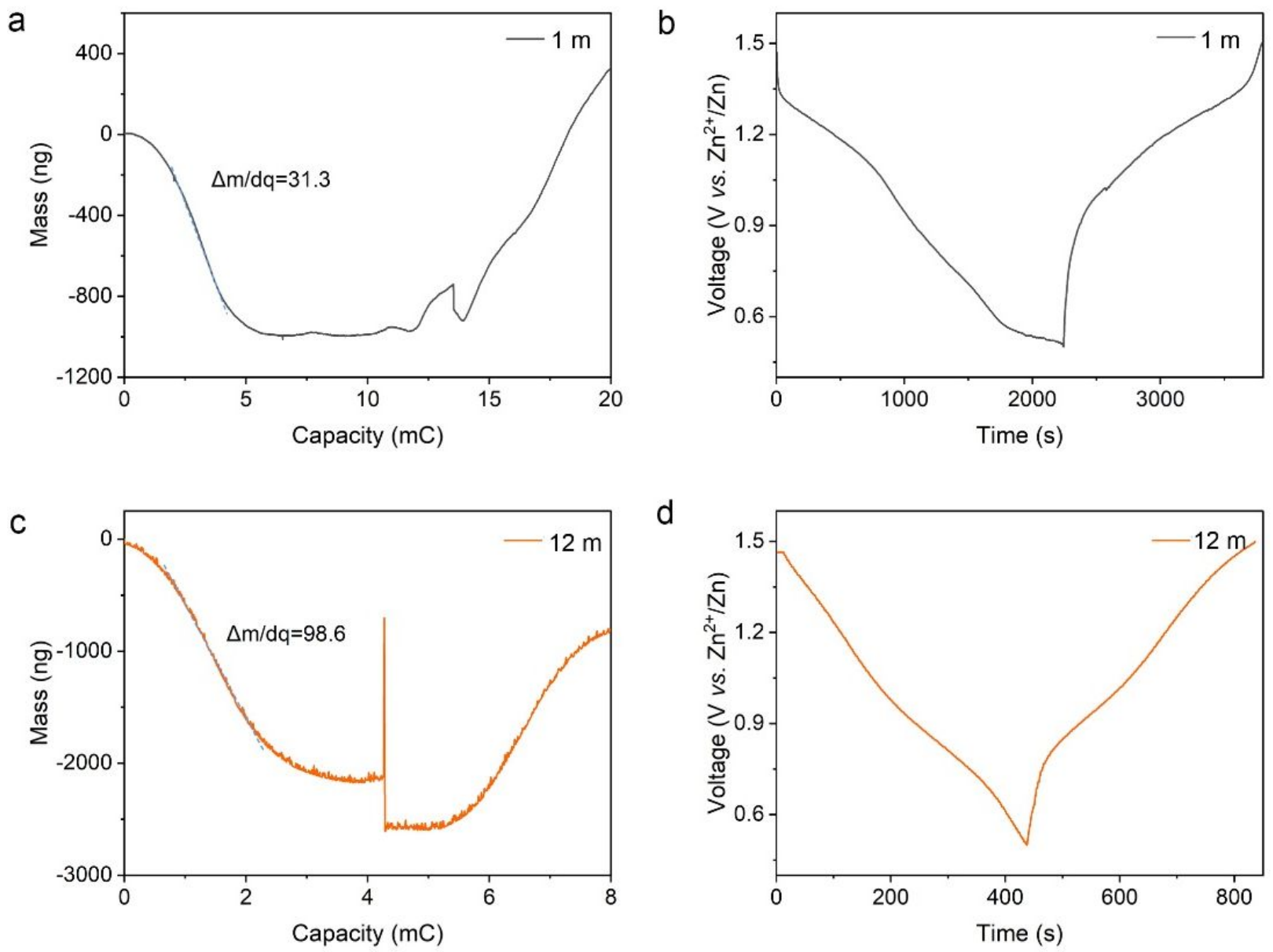

d
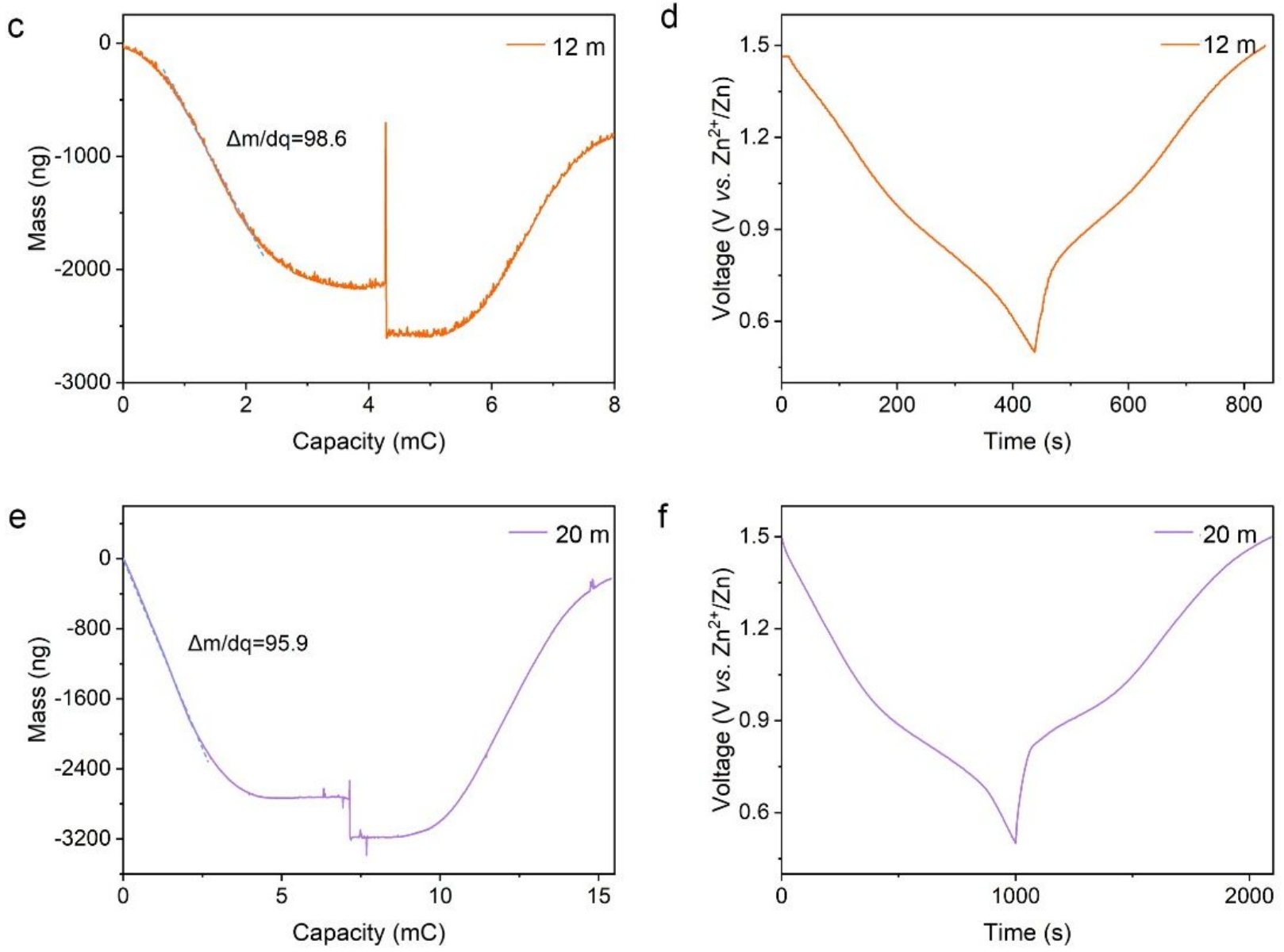

Figure S27. Mass vs. charge curve from EQCM and corresponding charging and discharging curve of Zn||PANI battery in the (a-b) $1.0 \mathrm{~m}$, (c-d) $12.0 \mathrm{~m}$ and (e-f) $20.0 \mathrm{~m} \mathrm{ZnCl} 2$ electrolyte. 
The quartz crystal analyzer QCM-922 system measures the resonant resistance and resonant frequency of a quartz crystal resonator simultaneously during electrochemical tests. The area of 9 MHz AT-cut quartz crystal oscillators was $0.2 \mathrm{~cm}^{2}$. The QA-CL4 well cell resonator holder with PANI coated quartz crystal, and $\mathrm{Zn}$ foil are used as the working, counter, and reference electrodes, respectively. The mass change $(\Delta m)$ of ion/cluster insertion/extraction coupled to the quartz surface should follow the Sauerbrey equation $3: 4$

$$
\Delta f=\frac{-2 f_{0}^{2}}{A \sqrt{\rho_{Q} \mu_{Q}}} \times \Delta m
$$

where $\Delta f, f_{0}^{2}, A, \rho_{Q}$, and $\mu_{Q}$ represents frequency change, resonant frequency of the quartz crystal, piezoelectrically active crystal area (or electrode area), density of quartz $\left(2.648 \mathrm{~g} \mathrm{~cm}^{-3}\right)$, and shear modulus of quartz $\left(2.947 \times 10^{11} \mathrm{~g} \mathrm{~cm}^{-1} \mathrm{~s}^{-2}\right)$, respectively.

In dilute electrolyte, $\mathrm{Zn}^{2+}$ insertion/extraction into/from the PANI nanorods with the mass change per electron $\Delta \mathrm{m} / \mathrm{dq}=62.6 \mathrm{~g} \mathrm{~mol}^{-1}$ of $2 \mathrm{e}^{-1}$, which is fairly close to the relative atomic mass of $\mathrm{Zn}\left(65.4 \mathrm{~g} \mathrm{~mol}^{-1}\right)$. While in moderate and high concentrated electrolyte, the results indicate the $[\mathrm{ZnC}]^{+}\left(100.8 \mathrm{~g} \mathrm{~mol}^{-1}\right)$ insertion/extraction mechanism. Limited by the high viscosity of $30.0 \mathrm{~m}$ $\mathrm{ZnCl}_{2}$ electrolyte, the EQCM is hard to apply in this system. Considering the similar physicochemical properties of $20.0 \mathrm{~m}$ and $30.0 \mathrm{~m} \mathrm{ZnCl} 2$ electrolyte (both are molten hydrate electrolytes) and $\mathrm{Cl}^{-}$is hard to extract from $[\mathrm{ZnCl}]^{+}$during the desolvation process, it is reasonable to infer the $\left[\mathrm{ZnCl}^{+}\right.$insertion/extraction mechanism in the highly concentrated electrolyte. 
Table S1. Detailed data for calculating the ratio of surface free energy and nucleation overpotential $\gamma_{S L} \eta$ (Figure S7).

\begin{tabular}{|c|c|c|c|c|c|c|}
\hline Electrolyte & $\begin{array}{c}\text { Surface } \\
\text { tension } \gamma_{L V} \\
\mathrm{mN} / \mathrm{m}\end{array}$ & $\begin{array}{l}\text { Contact } \\
\text { angle } \theta^{\circ}\end{array}$ & $\begin{array}{c}\text { Surface } \\
\text { energy } \gamma_{S L} \\
\mathrm{mN} / \mathrm{m}\end{array}$ & $\begin{array}{c}\text { Plateau } \\
\text { overpotential } \\
\eta_{p} \mathrm{mV}\end{array}$ & $\begin{array}{c}\text { Nucleation } \\
\text { overpotential } \eta \\
\mathrm{mV}\end{array}$ & $\gamma_{S L / \eta}$ \\
\hline $1.0 \mathrm{~m} \mathrm{ZnCl}_{2}$ & 69.04 & 83.7 & 28.10 & 62.91 & 10.47 & 2.68 \\
\hline $5.0 \mathrm{~m} \mathrm{ZnCl}_{2}$ & 55.91 & 77.5 & 23.58 & 55.69 & 12.55 & 1.87 \\
\hline $10.0 \mathrm{~m} \mathrm{ZnCl}_{2}$ & 51.15 & 76.9 & 24.07 & 54.72 & 19.06 & 1.26 \\
\hline $12.0 \mathrm{~m} \mathrm{ZnCl}_{2}$ & 49.19 & 76.6 & 24.27 & 54.15 & 33.36 & 0.73 \\
\hline $15.0 \mathrm{~m} \mathrm{ZnCl}_{2}$ & 45.15 & 75.8 & 24.51 & 62.53 & 22.70 & 1.08 \\
\hline $20.0 \mathrm{~m} \mathrm{ZnCl}_{2}$ & 44.34 & 74.5 & 23.82 & 66.92 & 17.92 & 1.33 \\
\hline $30.0 \mathrm{~m} \mathrm{ZnCl}_{2}$ & 39.90 & 72.4 & 23.61 & 100.50 & 16.01 & 1.47 \\
\hline
\end{tabular}


Table S2. Electronic conductivity, viscosity, and diffusion coefficient of different concentrated electrolytes (Figure S10).

\begin{tabular}{cccc}
\hline Electrolyte & $\begin{array}{c}\text { Electronic conductivity } \\
\mathrm{mS} / \mathrm{cm}\end{array}$ & $\begin{array}{c}\text { Viscosity } \\
\mathrm{mPa} \mathrm{s}\end{array}$ & $\begin{array}{c}\text { Diffusion coefficient } \\
\times 10^{-7} \mathrm{~cm}^{-2} / \mathrm{s}\end{array}$ \\
\hline $1.0 \mathrm{~m} \mathrm{ZnCl}_{2}$ & 61.70 & 1.09 & 1.02 \\
$5.0 \mathrm{~m} \mathrm{ZnCl}_{2}$ & 69.40 & 1.61 & 4.51 \\
$10.0 \mathrm{~m} \mathrm{ZnCl}_{2}$ & 48.40 & 2.99 & 4.74 \\
$12.0 \mathrm{~m} \mathrm{ZnCl}_{2}$ & 36.20 & 4.33 & 7.30 \\
$15.0 \mathrm{~m} \mathrm{ZnCl}_{2}$ & 26.90 & 6.84 & 6.67 \\
$20.0 \mathrm{~m} \mathrm{ZnCl}_{2}$ & 17.30 & 14.45 & 3.29 \\
$30.0 \mathrm{~m} \mathrm{ZnCl}_{2}$ & 9.20 & 60.42 & 1.57 \\
\hline
\end{tabular}


Table S3. Weight retention of different concentrated electrolytes at room temperature (Figure S10).

\begin{tabular}{cccccccr}
\hline Electrolyte & \multicolumn{7}{c}{ Weight retention } \\
\cline { 2 - 8 } & 0 day & 1 day & 2 day & 3 day & 5 day & 10 day & 20 day \\
\hline $1.0 \mathrm{~m} \mathrm{ZnCl}_{2}$ & 1.00 & 0.88 & 0.74 & 0.60 & 0.35 & 0.19 & 0.22 \\
$5.0 \mathrm{~m} \mathrm{ZnCl}_{2}$ & 1.00 & 0.93 & 0.85 & 0.80 & 0.75 & 0.68 & 0.72 \\
$10.0 \mathrm{~m} \mathrm{ZnCl}_{2}$ & 1.00 & 0.99 & 0.99 & 1.00 & 1.01 & 0.98 & 1.03 \\
$12.0 \mathrm{~m} \mathrm{ZnCl}_{2}$ & 1.00 & 1.01 & 1.03 & 1.05 & 1.08 & 1.06 & 1.11 \\
$15.0 \mathrm{~m} \mathrm{ZnCl}_{2}$ & 1.00 & 1.03 & 1.07 & 1.10 & 1.15 & 1.14 & 1.19 \\
$20.0 \mathrm{~m} \mathrm{ZnCl}_{2}$ & 1.00 & 1.05 & 1.10 & 1.16 & 1.22 & 1.24 & 1.30 \\
$30.0 \mathrm{~m} \mathrm{ZnCl}_{2}$ & 1.00 & 1.06 & 1.13 & 1.20 & 1.29 & 1.35 & 1.41 \\
$1.0 \mathrm{M} \mathrm{ZnSO}_{4}$ & 1.00 & 0.87 & 0.72 & 0.57 & 0.31 & 0.24 & 0.22 \\
$3.0 \mathrm{M} \mathrm{ZnSO}_{4}$ & 1.00 & 0.88 & 0.75 & 0.64 & 0.57 & 0.57 & 0.56 \\
$1.0{\mathrm{M} \mathrm{Zn}(\mathrm{OTF})_{2}}$ & 1.00 & 0.89 & 0.77 & 0.65 & 0.49 & 0.39 & 0.36 \\
$3.0{\mathrm{M} \mathrm{Zn}(\mathrm{OTF})_{2}}^{1.00}$ & 1.00 & 0.97 & 0.95 & 0.94 & 0.90 & 0.87 & 0.86 \\
$\mathrm{H}_{2} \mathrm{O}$ & 1.00 & 0.87 & 0.71 & 0.54 & 0.22 & 0.00 & 0.00 \\
\hline
\end{tabular}


Table S4. Coulombic efficiency of first ten cycles in various concentrations of $\mathrm{ZnCl}_{2}$ electrolyte (Figure S14).

\begin{tabular}{cccccccc}
\hline CE & $1.0 \mathrm{~m}$ & $5.0 \mathrm{~m}$ & $10.0 \mathrm{~m}$ & $12.0 \mathrm{~m}$ & $15.0 \mathrm{~m}$ & $20.0 \mathrm{~m}$ & $30.0 \mathrm{~m}$ \\
& $\mathrm{ZnCl}_{2}$ & $\mathrm{ZnCl}_{2}$ & $\mathrm{ZnCl}_{2}$ & $\mathrm{ZnCl}_{2}$ & $\mathrm{ZnCl}_{2}$ & $\mathrm{ZnCl}_{2}$ & $\mathrm{ZnCl}_{2}$ \\
\hline 1st & 0.8560 & 0.8139 & 0.9392 & 0.9786 & 0.9416 & 0.8243 & 0.9089 \\
2nd & 0.7293 & 0.9731 & 0.9730 & 0.9825 & 0.9697 & 0.8982 & 0.8064 \\
3rd & 0.6978 & 0.9866 & 0.9860 & 0.9885 & 0.9751 & 0.9373 & 0.8215 \\
4th & 0.6613 & 0.9835 & 0.9849 & 0.9905 & 0.9807 & 0.9628 & 0.8352 \\
5th & 0.6380 & 0.9917 & 0.9879 & 0.9916 & 0.9855 & 0.9742 & 0.8407 \\
6th & 0.6363 & 1.0036 & 0.9938 & 0.9918 & 0.9909 & 0.9833 & 0.8408 \\
7th & 0.6278 & 1.0077 & 0.9870 & 0.9912 & 0.9919 & 0.9897 & 0.8487 \\
8th & 0.6049 & 0.9918 & 0.9829 & 0.9916 & 0.9916 & 0.9875 & 0.8469 \\
9th & 0.6252 & 0.9866 & 0.9907 & 0.9919 & 0.9923 & 0.9901 & 0.8566 \\
10th & 0.6190 & 0.9843 & 0.9879 & 0.9908 & 0.9899 & 0.9677 & 0.8524 \\
average & 0.6699 & 0.9731 & 0.9815 & 0.9890 & 0.9807 & 0.9503 & 0.8462 \\
error & 0.0607 & 0.0625 & 0.0166 & 0.0038 & 0.0138 & 0.0431 & 0.0115 \\
\hline
\end{tabular}


Table S5. Exchange current densities in various concentrations of $\mathrm{ZnCl}_{2}$ electrolyte (Figures 5a and S15).

\begin{tabular}{cc}
\hline Electrolyte & $\begin{array}{c}\text { Exchange current density } \\
\mathrm{mA} \mathrm{cm}^{-2}\end{array}$ \\
$1.0 \mathrm{~m} \mathrm{ZnCl}_{2}$ & 2.758 \\
$5.0 \mathrm{~m} \mathrm{ZnCl}_{2}$ & 3.059 \\
$10.0 \mathrm{~m} \mathrm{ZnCl}_{2}$ & 3.094 \\
$12.0 \mathrm{~m} \mathrm{ZnCl}_{2}$ & 3.120 \\
$15.0 \mathrm{~m} \mathrm{ZnCl}_{2}$ & 1.727 \\
$20.0 \mathrm{~m} \mathrm{ZnCl}_{2}$ & 1.023 \\
$30.0 \mathrm{~m} \mathrm{ZnCl}_{2}$ & 0.425 \\
\hline
\end{tabular}


Table S6. Abundance of $\mathrm{Zn}^{2+}$ clusters in $1.0 \mathrm{~m}, 12.0 \mathrm{~m}, 30.0 \mathrm{~m} \mathrm{ZnCl}_{2}$ electrolyte at 1 bar, $25{ }^{\circ} \mathrm{C}$ (Figure 5b).

\begin{tabular}{lccc}
\hline Clusters & \multicolumn{3}{c}{ Electrolyte } \\
\cline { 2 - 4 } & $1.0 \mathrm{~m} \mathrm{ZnCl}_{2}$ & $12.0 \mathrm{~m} \mathrm{ZnCl}_{2}$ & $30.0 \mathrm{~m} \mathrm{ZnCl}_{2}$ \\
\hline $\mathrm{Zn}\left(\mathrm{H}_{2} \mathrm{O}\right)_{6}^{2+}$ & 60.0 & 1.2 & 3.0 \\
$\mathrm{ZnCl}^{2+}\left(\mathrm{H}_{2} \mathrm{O}\right)_{5}^{2+}$ & 30.0 & 46.3 & 11.3 \\
$\mathrm{ZnCl}_{2}\left(\mathrm{H}_{2} \mathrm{O}\right)_{2}$ & $/$ & 14.6 & 7.7 \\
$\mathrm{ZnCl}_{3} \mathrm{H}_{2} \mathrm{O}^{-}$ & 10.0 & 30.4 & 51.5 \\
$\mathrm{ZnCl}_{4}{ }^{2-}$ & $/$ & 7.5 & 26.5 \\
\end{tabular}


Table S7. Total molecular energy [a.u.] (1 a.u. $=627.5095 \mathrm{kcal} / \mathrm{mol})$ and free energy $(\Delta \mathrm{E}$, $\mathrm{kcal} / \mathrm{mol}$ ) of complexes in $1.0 \mathrm{~m}, 12.0 \mathrm{~m}$ and $30.0 \mathrm{~m} \mathrm{ZnCl}_{2}$ electrolyte (Figure $5 \mathrm{c}-\mathrm{e}$ ).

\begin{tabular}{cc}
\hline & $m 062 x /$ def2tzvp \\
\hline $\mathrm{Zn}^{2+}$ & -1778.39686 \\
$\mathrm{Cl}^{-}$ & -460.27098 \\
$\mathrm{H}_{2} \mathrm{O}$ & -76.42220 \\
\hline
\end{tabular}

1.0 $\mathbf{m ~} \mathrm{ZnCl}_{2}$ electrolyte (free energy relative to $\mathrm{Zn}^{2+}$ ):

\begin{tabular}{cccc}
\hline Structure & $\mathrm{Zn}^{2+}+6 \mathrm{H}_{2} \mathrm{O}$ & $\mathrm{Zn}^{2+}+5 \mathrm{H}_{2} \mathrm{O}$ & $\mathrm{Zn}^{2+}+4 \mathrm{H}_{2} \mathrm{O}$ \\
\hline $\mathrm{m} 062 \mathrm{x} /$ def2tzvp & -2237.42233 & -2160.96852 & -2084.51339 \\
$\Delta \mathrm{E}$ & 308.88866 & 289.05432 & 268.40171 \\
Geometry & & & \\
Bond lengths of & & & \\
$\mathrm{Zn}-\mathrm{O}(\AA)$
\end{tabular}




\begin{tabular}{|c|c|c|c|c|}
\hline Structure & $\mathrm{Zn}^{2+}+3 \mathrm{H}_{2} \mathrm{O}$ & $\mathrm{Zn}^{2+}+2 \mathrm{H}_{2} \mathrm{O}$ & $\mathrm{Zn}^{2+}+\mathrm{H}_{2} \mathrm{O}$ & $\mathrm{Zn}^{2+}$ \\
\hline $\mathrm{m} 062 \mathrm{x} / \mathrm{def} 2 \mathrm{tzvp}$ & -2008.02754 & -1931.52157 & -1854.97094 & -1778.39686 \\
\hline$\Delta \mathrm{E}$ & 228.45694 & 175.89231 & 95.30622 & 0.00000 \\
\hline \multicolumn{5}{|l|}{ Geometry } \\
\hline Bond lengths of & 1.94195 & 1.87900 & 1.88100 & l \\
\hline $\mathrm{Zn}-\mathrm{O}(\AA)$ & & & & \\
\hline
\end{tabular}

12.0 $\mathbf{~} \mathrm{ZnCl}_{2}$ electrolyte (free energy relative to $\mathrm{ZnCl}^{+}$):

\begin{tabular}{|c|c|c|c|}
\hline Structure & $\mathrm{ZnCl}^{+}+5 \mathrm{H}_{2} \mathrm{O}$ & $\mathrm{ZnCl}^{+}+4 \mathrm{H}_{2} \mathrm{O}$ & $\mathrm{ZnCl}^{+}+3 \mathrm{H}_{2} \mathrm{O}$ \\
\hline $\mathrm{m} 062 \mathrm{x} / \mathrm{def} 2 \mathrm{tzvp}$ & -2621.59061 & -2545.15474 & -2468.71422 \\
\hline$\Delta \mathrm{E}$ & 121.65159 & 113.08169 & 101.58320 \\
\hline Geometry & & & \\
\hline Bond lengths of & 2.09801 & 2.05230 & 2.04779 \\
\hline \multicolumn{4}{|l|}{$\mathrm{Zn}-\mathrm{O}(\AA)$} \\
\hline Bond lengths of & 2.26101 & 2.19672 & 2.14680 \\
\hline $\mathrm{Zn}-\mathrm{Cl}(\AA)$ & & & \\
\hline
\end{tabular}




\begin{tabular}{|c|c|c|c|}
\hline Structure & $\mathrm{ZnCl}^{+}+2 \mathrm{H}_{2} \mathrm{O}$ & $\mathrm{ZnCl}^{+}+\mathrm{H}_{2} \mathrm{O}$ & $\mathrm{ZnCl}^{+}$ \\
\hline $\mathrm{m} 062 \mathrm{x} / \mathrm{def} 2 \mathrm{tzvp}$ & -2392.25921 & -2315.79143 & -2239.28572 \\
\hline$\Delta \mathrm{E}$ & 80.99774 & 52.39709 & 0.00000 \\
\hline \multicolumn{4}{|l|}{ Geometry } \\
\hline Bond lengths of & 2.00625 & 1.92500 & / \\
\hline \multicolumn{4}{|l|}{$\mathrm{Zn}-\mathrm{O}(\AA)$} \\
\hline Bond lengths of & 2.10600 & 2.06800 & 2.07900 \\
\hline $\mathrm{Zn}-\mathrm{Cl}(\AA)$ & & & \\
\hline
\end{tabular}

30.0 $\mathbf{~} \mathrm{ZnCl}_{2}$ electrolyte (free energy relative to $\mathrm{ZnCl}^{+}$):

\begin{tabular}{|c|c|c|c|c|}
\hline Structure & $\mathrm{ZnCl}_{4}{ }^{3-}+\mathrm{H}_{2} \mathrm{O}$ & $\mathrm{ZnCl}^{+}+2 \mathrm{Cl}^{-}$ & $\mathrm{ZnCl}^{+}+\mathrm{Cl}^{-}$ & $\mathrm{ZnCl}^{+}$ \\
\hline m062x/def2tzvp & -3236.70579 & -3160.27930 & -2699.9032 & -2239.28572 \\
\hline$\Delta \mathrm{E}$ & 286.08934 & 283.39669 & 217.43723 & 0.00000 \\
\hline \multicolumn{5}{|l|}{ Geometry } \\
\hline Bond lengths of & 2.29889 & 2.23933 & 2.11300 & 2.07900 \\
\hline $\mathrm{Zn}-\mathrm{Cl}(\AA)$ & & & & \\
\hline
\end{tabular}


Note S1. Derivation process of critical nucleation radius and areal nuclei density. ${ }^{5,6}$

For heterogeneous nucleation, such as the $\mathrm{Zn}$ deposited on an electrode surface, the initial nucleation with the nucleus formed as a cluster growth in all dimensions. A semi-spherical cluster can be depicted as a few atoms. Thus, the Gibbs free energy of the nucleus is calculated as following:

$$
\Delta g_{n u l i}=\Delta g_{b u l k}+\Delta g_{\text {surf }}=-\frac{2 \pi r^{3} z F \eta}{3 V_{m}}+2 \pi r^{2} \gamma_{S L}
$$

where $V_{m}$ is the molar volume of $\mathrm{Zn}, \gamma_{S L}$ the surface free energy of Zn-electrolyte interface, $z$ the number of electrons per monomer unit, $F$ the Faraday's constant, $\eta$ the nucleation overpotential. From the equation $d \Delta g_{\text {nuli }} / d r=0$, the critical nucleation radius $r_{c r i t}$ can be obtained:

$$
r_{c r i t}=\frac{2 V_{m} \gamma_{S L}}{z F \eta}
$$

For a semi-spherical nucleus, the critical nucleation volume $V_{c r i t}=\frac{1}{2} \frac{4 \pi}{3} r_{c r i t}^{3}$. By inserting $V_{c r i t}$ one obtains the areal nucleation density $N_{\text {crit }}$ :

$$
N_{c r i t}=\frac{3 z^{3} F^{3} \eta^{3}}{16 \pi N_{A} V_{m}^{2} \gamma_{S L}^{3}}
$$

where $N_{A}$ is the Avogadro constant.

In the condition of exploring the effect of applied current density or operating temperature of a cell, there is only one variable parameter in this system, that is the nucleation overpotential $\eta$. Immediately, it is apparent that there is an inverse relationship between critical nuclei radius and overpotential, as well as a cube relationship between areal nuclei density and overpotential. In other words, enlarging the nucleation overpotential, such as improving current density or reducing the temperature, is helpful for a smaller nucleation radius and dense nuclei distribution.

While considering the effect of electrolyte constituent for initial nucleation, for instance, considering concentration or electrolyte addition, the overpotential as well as the surface free energy codetermine the semi-spherical cluster. Apparently, the $r_{c r i t}$ is directly proportional to $\gamma_{S L} / \eta$, the $N_{c r i t}$ is inversely proportional to $\left(\gamma_{S L} / \eta\right)^{3}$. 


\section{Supplementary references:}

(1) Zheng, J.; Zhao, Q.; Tang, T.; Yin, J.; Qulity, C.; Renderos, G. D.; Liu, X.; Deng, Y.; Wang, L.; Bock, D. C.; Jaye, C.; Zhang, D.; Takeuchi, E. S.; Takeuchi, K. J.; Marschilok, A. C.; Archer,

L. A. Reversible Epitaxial Electrodeposition of Metals in Battery Anodes. Science 2019, 366, 645-648.

(2) Sun, K. E. K.; Hoang, T. K. A.; The Nam Long, D.; Yu, Y.; Chen, P. Highly Sustainable Zinc Anodes for a Rechargeable Hybrid Aqueous Battery. Chem. Eur. J. 2018, 24, 1667-1673.

(3) Huang, S.; Wan, F.; Bi, S.; Zhu, J.; Niu, Z.; Chen, J. A Self-Healing Integrated All-in-One Zinc-Ion Battery. Angew. Chem. Int. Ed. 2019, 58, 4313-4317.

(4) Liu, T.; Lin, L.; Bi, X.; Tian, L.; Yang, K.; Liu, J.; Li, M.; Chen, Z.; Lu, J.; Amine, K.; Xu, K.; Pan, F. In Situ Quantification of Interphasial Chemistry in Li-Ion Battery. Nat. Nanotechnol. 2018, 14, 50-56.

(5) Plieth, W. Electrochemistry for Materials Science; Elsevier: Amsterdam, 2008; pp 195-203.

(6) Pei, A.; Zheng, G.; Shi, F.; Li, Y.; Cui, Y. Nanoscale Nucleation and Growth of Electrodeposited Lithium Metal. Nano Lett. 2017, 17, 1132-1139. 